\title{
A Comparison of Computerized Chemical Models for Equilibrium Calculations in Aqueous Systems ${ }^{1}$
}

\author{
D. K. NORDSTROM ${ }^{2}$, L. N. PLUMMER ${ }^{3}$, T. M. L. WIGLEY, T. J. WOLERY ${ }^{s}$, \\ J. W. BALL ${ }^{6}$, E. A. JENNE ${ }^{6}$, R. L. BASSETT ${ }^{7}$, D. A. CRERAR ${ }^{8}$, T. M. FLORENCE ${ }^{9}$, \\ B. FRITZ ${ }^{10}$, M. HOFFMAN ${ }^{\prime \prime}$, G. R. HOLDREN, JR. ${ }^{12}$, G. M. LAFON ${ }^{1,}$, \\ S. V. MATTIGOD ${ }^{14}$ R. E. McDUFF ${ }^{15}$,F. MOREL ${ }^{15}$, M. M. REDDY ${ }^{16}$, G. SPOSITO $^{14}$, \\ and J. THRAILKILL"
}

The interpretation of chemical processes in aqueous systems requires the use of modern electronic computers, particularly in the calculation of multicomponent, multiphase equilibria. Commonly, the first concern of solution chemists and aqueous geochemists is to calculate the distribution and activities of species on the assumption that equilibrium exists throughout the aqueous phase. Species distribution can then be used in several areas of analytical and applied chemistry, e.g. to examine the availability of free and reactive ions, to test solubility hypotheses, and to determine the potential bioavailability of nutrients or toxic substances. Species distribution also forms the basis for more complex computations involving solutions which change composition by reaction with other solutions and with gases and solids. Equilibrium calculations of this type are particularly helpful in solving interpretive problems encountered in such fields as chemical and environmental engineering, geochemistry, biochemistry and aquatic ecology.

This symposium demonstrates quite clearly that we depend heavily on chemical models, especially computerized models, to interpret aqueous chemical processes. Several computer programs which solve problems of simultaneous chemical equilibria are being used by a rapidly increasing number of investigators and it is necessary to review the inherent assumptions and limitations of these aqueous models. There is a temptation to use these models as ready-made interpretations

\footnotetext{
${ }^{1}$ Current addresses for authors can be found on page 892 .
} 
of reality without a clear understanding of their weaknesses. These programs and models are usually developed for specific purposes and taken together they represent a wide range of capabilities and features. This paper reviews the state-ofthe-art of equilibrium computations by providing a compilation and description of aqueous models in current use and by examining their consistency through a comparison of species distributions and saturation indices for two hypothetical test cases: a river water sample and a seawater sample. This review will also serve to complement the review on machine computation efficiency by Leggett (1) and the review by Perrin (2) on the applications of digital computers to analytical chemistry.

The Chemical Equilibrium Problem and Its Thermodynamic Basis

An "aqueous chemical model" needs to be defined separately from the computer program which executes calculations based on the model. Such a model can be defined as a theoretical construction which allows us to predict the thermodynamic properties of electrolyte solutions. There are several ways of constructing an aqueous modeT, e.g. from the Bjerrum ion association theory $(3)$, or the Fuoss ion association theory $(4,5)$ or the Reilly, Wood and Robinson mixed electrolyte theory (6). The choice of model must be made on the basis of the problem to be solved and each model carries with it its own set of assumptions and restrictions. Nearly all computerized models are based on the ion association theory and within this framework the species distribution problem can be formulated in two distinct but thermodynamically related ways: the equilibrium constant approach and the Gibbs free energy approach. Both approaches are subject to the conditions of 1) mass balance and of 2) chemical equilibrium. The mass balance condition requires that the computed sum of the free and derived (complexes) species be equal to the given total concentration. Chemical equilibrium requires that the most stable arrangement for a given system be found, as defined by the equilibrium constants for all mass action expressions of the system, or through the use of Gibbs free energies for all of the components and derived species. In the equilibrium constant approach the mass action expressions are substituted into the mass balance conditions resulting in a set of nonlinear equations which must be solved simultaneously. The Gibbs free energy approach is simply a transformation of variables through the thermodynamic relation:

$$
\Delta G_{r}=\Delta G_{r}^{0}+R T I n K=0
$$

which allows a different numerical approach. The total Gibbs 
free energy function is then minimized for a given set of species and their mole numbers subject to the mass balance requirement. In the former approach equilibrium constants are needed for the data base whereas in the latter approach free energy values are needed. This difference in the data base can often be an important limitation. At the present time there are more reliable and available equilibrium constants than free energy values.

By either thermodynamic approach the problem can be stated numerically as one of finding a solution to a set of nonlinear equations. It is usually not feasible to simultaneously solve these equations in exact form for a multicomponent, multiphase system and therefore an iteration procedure must be utilized. The standard method of solving the problem by the equilibrium constant approach is to use linearized matrix inversion. Convergence assumes, of course, that the solution not only exists but that it is unique. If a system can have several thermodynamically metastable states (local minima in the Gibbs function) then several nonunique solutions are possible. Recent papers by Othmer (7) and Caram and Scriven (8) have pointed out that uniqueness is characteristic of ideal systems whereas for non-ideal systems a solution may occur at the global minimum (most stable equilibrium point) but it also may occur at a nonunique local minimum. For applications in aquatic chemistry the problem of nonuniqueness is particularly important in the interpretation of solid precipitation and dissolution processes.

The choice of the thermodynamic approach dictates the general category of numerical techniques to be used. Optimization techniques such as pattern search, linear programming, steepest descent and gradient methods are all appropriate to the Gibbs function approach whereas NewtonRaphson, successive approximations and nested iterations are best suited to the equilibrium constant approach. These techniques and several other mathematical methods have been documented along with the thermodynamic formalism in the excellent reviews by Zeleznik and Gordon (9) and Van Zeggeren and Storey (10). In this report we prefer to describe the main features and capabilities of current models rather than digress on the mathematical details of each since "... any method of calculation that can be made reliable is a good method when equilibrium compositions are the only concern" (9).

Chemical models can be further characterized by their application. The intended utilization of a model usually directs the developmental stages of choosing the type of model and the mathematical method. We have grouped current computerized models into "major schools" according to their point of origin and their application. Since the second generation models frequently used the same basic numerical approach as their predecessors, the classification into schools also tends to separate different mathematical formulations. 
Major Schools of Computerized Models

Generalized Method of the Equilibrium Constant Approach. The basic mathematics of the equilibrium constant approach was derived in general form by Brinkley $(11,12)$ and Kandiner and Brinkley (13). The development of the equations was well suited for adaptation to digital computers and Feldman, et al. (14) utilized the approach to calculate the equilibrium composition of high temperature gaseous mixtures. This approach has been strongly favored by geochemists. For example, Crerar (15) has revised this method so that arbitrary independent equilibrium constants can be used. He employed Newton-Raphson iteration with curve-crawler techniques (16) for rapid convergence and applied his routine to problems of hydrothermal chemistry. It should be pointed out that these methods are completely general, in the mathematical sense, so that only the reactions taking place in the system under investigation need be coded for computation. This routine can be useful for laboratory and experimental systems where most of the species and associated data base of non-general programs are unnecessary.

Generalized Method of the Gibbs Free Energy Minimization. The mathematical formulation of the free energy approach was pioneered by White et al. (17) who pointed out the advantages of using al ternative numerical techniques such as steepest descent and linear programming. Dayhoff et al. (18) computed equilibrium compositions for prebiological and planetary atmospheres with this approach and showed how these compositions changed at different temperatures and pressures for systems containing $\mathrm{C}, \mathrm{H}, \mathrm{O}, \mathrm{N}, \mathrm{P}, \mathrm{S}$ and $\mathrm{Cl}$. Holloway and Reese (19) have solved the equilibrium composition of the system $\mathrm{C}-0-\mathrm{H}-\mathrm{N}$ at high temperatures by a computerized free energy minimization model and Karpov and $\mathrm{Kaz}^{\circ}$ min (20) have computed the distribution of species in seawater using a dual al gorithm technique. For relatively simple systems where the free energies are available and reliable, the Gibbs minimization approach is convenient and dependable. For large complex systems, however, the equilibrium constant approach is preferred. If and when an accurate and internally consistent set of thermodynamic data becomes available, the Gibbs minimization will likely find greater use. We now present a brief review of non-general computerized models which uses the equilibrium constant approach and incorporates individual reactions as part of the program.

Specific Programs in Analytical Chemistry. Following the lead of Brinkley and others, several programs were independently developed to solve problems involving aqueous equilibria in analytical and physical chemistry. One of the earliest programs, HALTAFALL, came from the work of sillen and his 
colleagues $(21,22)$. This program was designed to calculate species distribution in an aqueous phase from a knowledge of the appropriate stability constants and total concentrations. The program is general enough to handle mixing problems such as titrations involving separation of gaseous or solid phases and organic solvent extractions. The computations are carried out at constant ionic strengh and constant temperature although these restrictions can be modified by the programmer. When apparent stability constants at different ionic strengths than the equilibrium problem are used, corrections are made by the Davies equation $(80)$. The general method of calculation is by successive approximation. A companion program, LETAGROP VRID, was written to calculate stability constants for aqueous complexes from various measurements (23). Both programs are written in ALGOL. Perrin (24) and Perrin and Sayce (25) developed the COMICS program for the calculation of the equilibrium distribution of species using a type of "brute force" successive approximation (see below). COMICS has gone through several stages of modification which have been discussed by Leggett (1) and will not be further elaborated on here, except to mention a more recent version called SIAS (26). A similar program named EQBRAT is described by Detar (27) and it complements other programs (all in FORTRAN) which can handle a wide range of chemical problems. Bos and Meershoek (28) introduced Newton's method to titration calculations with the program EQUIL, written in $\mathrm{PL} / 1$, which increased the computation efficiency and was protected against non-convergence problems.

\section{Successive Approximation Programs For Natural Water} Equilibria. Garrels and Thompson (29) were the first to use the method of successive approximation in a hand calculation to solve an equilibrium problem in aqueous geochemistry. Their analysis of the species distribution in seawater in terms of ion association influenced the development of several models. Barnes and Clarke (30) found this approach useful in the investigation of the corrosion properties of wells and developed the WATCHEM program to interpret iron corrosion processes. This approach was also used to initialize PATHI (31) by a subroutine called SOLSAT which existed as a separate program. A recent version of this program, called EQUIL, has evolved from the work of Fritz (32) and Droubi (33) and it is used with the programs DISSOL and EVAPOR mentioned below. The most general first-generation programs of this type are WATEQ $(34,35)$, SOLMNEQ $(36)$, and EQ3 $(37)$. A11 three programs have been designed to accept water anaTyses with on site values for $\mathrm{pH}$, Eh and temperature. There is no proton mass balance condition, only mass balances on cations and anions are carried out. SOLMNEQ carries a data base in the form of a table of equilibrium constants for the range $0-350^{\circ} \mathrm{C}$ and $E Q 3$ contains a similar data base for $0-300^{\circ} \mathrm{C}$ whereas WATEQ uses the Vant 
Hoff equation or analytical expessions for equilibrium constants as a function of temperature and is considered reliable for the range $0-100^{\circ} \mathrm{C}$. SOLMNEQ has additional features such as the silica and $\mathrm{Na}-\mathrm{K}-\mathrm{Ca}$ geothermometers for evaluating geothermal reservoir temperatures and includes several more trace element species than WATEQ. SOLMNEQ has been expanded to include organic complexes and ion exchange equilibria and uses the pressure dependence of the equilibrium constants. EQ3 also uses pressure dependent equilibrium constants. WATEQ was originally written in $\mathrm{PL} / 1$ and has been revised and translated into FORTRAN by Plummer et al. (38) in a program called WATEQF. Manganese speciation has been added to WATEQF and the successive approximation procedure was revised to give much faster convergence. 21 aqueous species and 17 minerals of uranium have been added to WATEQF in a recent modification (39). The advantages of using PL/1 optimizing code with reorganization into several subprogram blocks along with the expansion of the data base to include several trace elements and the rapid convergence of WATEQF have been incorporated into WATEQ2 (40). A shorter version, called WATSPEC, which is preferrable for handling routine water analyses has been published by Wigley (41).

The method of successive approximations has been conveniently described by Wigley (41) where either a "brute force" method or a "continued fraction" method can be used. The brute force method is the classical approach where mass action expressions are substituted directly into the mass balance conditions and solved for total concentrations which are then compared to the analytical values. In the continued fraction method, the non-linear equations are rearranged to solve for free ion concentrations which are initially assumed to be equal to the total concentrations, as detailed by Wigley (42). These two methods are best illustrated by a simple example. Assume a solution which contains free $\mathrm{Ca}^{2+}$ ions, free $\mathrm{CO} 2-$ ions, and only one ion pair: $\mathrm{CaCO}_{3}^{\circ} \cdot$ The mass balance conditions are given by

$$
\begin{aligned}
& \mathrm{mCa}(\text { total })=\mathrm{mCa}^{2+}+\mathrm{mCaCO}_{3}^{\circ} \\
& \mathrm{mCO}_{3}(\text { total })=\mathrm{mCO}_{3}^{2}-+\mathrm{mCaCO}_{3}^{\circ}
\end{aligned}
$$

with the restriction that (assuming an ideal solution)

$$
K=\frac{\mathrm{mCaCO}_{3}}{\left(\mathrm{mCa}^{2+}\right)\left(\mathrm{mCO}_{3}^{2+}\right)} \text { or } \mathrm{mCaCO}_{3}^{\circ}=\mathrm{K}\left(\mathrm{mCa}^{2+}\right)\left(\mathrm{mCO}_{3}^{2}\right)
$$

Substituting equation 3 into equations 1 and 2 gives

$$
m C a(\text { total })=\mathrm{mCa}^{2+}+\mathrm{K}\left(\mathrm{mCa}^{2+}\right)\left(\mathrm{mCO}_{3}^{2}-\right)
$$


and $\mathrm{mCO}_{3}($ total $)=\mathrm{mCO}_{3}^{-}+\mathrm{K}\left(\mathrm{mCa}^{2+}\right)\left(\mathrm{mCO}_{3}^{-}\right)$.

Using the brute force method,

$$
\begin{aligned}
& \mathrm{mCa}^{2+}=\mathrm{mCa}(\text { total })-\mathrm{K}\left(\mathrm{mCa}^{2+}\right)\left(\mathrm{mCO}_{3}^{2-}\right) \\
& \mathrm{mCO}_{3}^{2-}=\mathrm{mCO}_{3}(\text { total })-\mathrm{K}\left(\mathrm{mCa}^{2+}\right)\left(\mathrm{mCO}_{3}^{2-}\right)
\end{aligned}
$$

where $\mathrm{mCa}^{2+}$ and $\mathrm{mCO}_{3}^{2-}$ are assumed equal to $\mathrm{mCa}($ total) and $\mathrm{mCO}_{3}$ (total) for the first estimate. Equations 6 and 7 give new values for the free ion concentrations which are then used in the next iteration. Using the continued fraction method equations 4 and 5 are rearranged to

$$
\begin{aligned}
\mathrm{mCa}^{2+} & =\frac{\mathrm{mCa}(\text { total })}{1+\mathrm{KmCO}_{3}^{2-}} \\
\mathrm{mCO}_{3}^{2-} & =\frac{\mathrm{mCO}_{3}(\text { total })}{1+\mathrm{KmCa}^{2+}} .
\end{aligned}
$$

As before, the first estimate is made by assuming that free ion concentrations are equal to total concentrations but the second estimate comes from equations 8 and 9 which vary less than equations 6 and 7 because of the form of the equation. This alternate form of the equations produces a faster convergence as shown in an example given by Wigley (41) and al so converges more rapidly than Newton-Raphson. EQ $\overline{3}$ employs an additional control on the continued fraction method which generates monotone sequences $(43,44)$. Its chief virtues are strict error bounds and increased stability with respect to a wide range of analyses of aqueous solutions used as input.

Other programs of this general type include SEAWAT (45) which was specifically designed for seawater calculations, MIRE (46) which was specifically designed for anoxic marine pore waters, IONPAIR and NOPAIR (47) and CALCITE (48) which were designed for freshwaters in carbonate terrains and KATKLE 1 (49) which has been used for soil water geochemistry.

Newton-Raphson Programs for Experimental and Natural Water Equilibria. Morel and Morgan (49) developed the FORTRAN program REDEQL for the calculation of multicomponent metalligand equilibria with considerable flexibility and includes a large number of metal-ligand complexes. The program is based on the equilibrium constant approach and uses Newton-Raphson iteration to find the solution to a function which compares the difference between the total calculated component concentration and the total analytical component concentration. REDEQL has the capability of imposing mineral saturation to allow dissolution and/or precipitation of various solids. Another option is 
the calculation of interaction intensities and capacities $(50,51,52)$. This program and its subsequent modifications have led to several "second generation" programs which are widely used by environmental engineers: REDEQL2, MINEQL and GEOCHEM. This family of programs can simulate adsorption behavior using the James-Healy approach, the Schindler-Stumm complexation approach or a combination of surface complexation and electric double layer (53-59). These programs also contain a data base for a constant temperature of $25^{\circ} \mathrm{C}$, other temperatures cannot be calculated without changing all the equilibrium constants to those temperatures. MINEQL $(60)$ has greater clarity and flexibility in a more compact program which utilizes Gaussian elimination to solve the matrix equation. GEOCHEM (61, unpublished data) has a greatly expanded data base covering over 800 organic species and more than 2000 inoraanic species and it includes ion exchange reactions for simulating soil water reactions. Convergence problems are occasionally encountered with Newton-Raphson methods which are commonly caused by poor estimates of initial concentrations supplied by the programmer. However, several numerical techniques including under-relaxation, curve-crawling and pre-iteration optimization of starting estimates can greatly increase the reliability of the Newton-Raphson method $(15,37,62)$. A good example is provided by the program EQUIL (62) which utilizes matrix scaling, eigen vector analysis, matrix modifications and a convergence forcer to achieve rapid and reliable convergence.

Reaction Path Simulation. The first application of computer techniques to problems of mass transfer in geochemistry began with the work of Helgeson and colleagues $(63,64)$. The general approach of the program PATHI (31) is to describe a partial equilibrium reaction path ( $\mathrm{e} . \mathrm{g}$ - mineral dissolution and rock weathering) in terms of ordinary differential equations which are linear and can be solved by matrix algebra. The initial condition, which consists of an aqueous fluid, must be calculated by a species distribution iteration scheme such as the successive approximation method. Progressive reaction states can be computed by incrementing the progress variable, $\boldsymbol{\xi}$ (65), iteratively and checking the aqueous phase for saturation at each step and then dissolving or precipitating the required mass(es) of the appropriate mineral phase(s) to retain equilibrium. Thus, by integrating a set of differential equations a reaction path can be followed progressively until overall chemical equilibrium is reached by the specified system. This method has been applied to the study of weathering reactions, diagenesis, metamorphism and hydrothermal metasomatism (64), in the formation of ore deposits (66) and scaling of conduits caused by precipitation from geothermal brines (67). PATHI has been revised and modified to simulate granite weathering (32) and evaporation of closed basin lakes 
(36) with the programs DISSOL and EVAPOR which use a related program, EQUIL, to calculate species distribution. These programs have been applied to the prediction of soil salinity and optimal irrigation doses as well as the general evolution of soil water during evaporation $(68,69)$.

Several difficulties with PATHI $\overline{\text { Ted }}$ to very long execytion times and occasional abnormal program termination. Claude Herrick and others (67) greatly improved the efficiency by adopting high-order Gear integration techniques $(70,71)$. However, drift error incurred in the integration remains an annoyance, and the differential equation approach cannot be applied if the starting solution is supersaturated with any solids.

Wolery (37) has written a PATHI-like program, EQ6, which uses the Newton-Raphson method to solve the system of al gebraic equations instead of their differential counterparts at each stage of reaction progress. The drift problem is thereby avoided. Taylor's series expressions, based on finite differences, are utilized to follow the course of the simulation and to predict starting estimates at each new point of reaction progress. EQ6 has some affinities in its numerical approach to the REDEQL school and Crerar's (15) program and it can precipitate an equilibrium assemblage of precipitates from an initially supersaturated solution.

Another program well suited for reaction path simulation is MIX2 (72) which uses a regression technique on the charge balance condition for the aqueous phase in computing $\mathrm{pH}$ after a reaction step. MIX2 can solve problems in mixing and titration of aqueous solutions $(73,74)$, evaporation, heterogeneous equilibrium, and non-equilibrium heterogeneous reactions (75). Although MIX2 avoids the drift problems associated with PATHI, the aqueous model is limited to the major species in the system $\mathrm{CaO}-\mathrm{MgO}-\mathrm{Na}_{2} \mathrm{O}-\mathrm{K}_{2} \mathrm{O}-\mathrm{H}_{2} \mathrm{SO}_{4}-\mathrm{H}_{2} \mathrm{CO}_{3}-\mathrm{HCl}-\mathrm{H}_{2} \mathrm{O}$ and considers only one phase boundary ${ }^{2}{ }^{4}$ a time. More advanced mass transfer programs using a log linearization technique for simultaneous solution of mass action, mass balance and charge balance equation are in preparation (76) which have broad applications to mass transfer problems.

\section{Test Case Results}

Collectively, the programs mentioned above represent the "state of the art" in the calculation of the equilibrium distribution of species in aqueous systems. As a means of examining the consistency of these programs, two test cases (a dilute river water and an average seawater analysis) were compiled and mailed to more than fifty researchers who have been active in the field of chemical modeling. These test cases may overlook many of the features of specific programs, but they provide a common basis by which most of the programs can be 
compared. One approach to the comparison of aqueous models is to tabulate and examine the thermodynamic data, activity coefficients, choice of complexes, etc. Alternatively the approach taken in this survey has been to examine the results predicted by the aqueous models, an approach that integrates all the aspects of each model. In this manner the differences between models can be seen in terms of the actual results which are of value in applications to specific problems. Differences will always be apparent between the thermodynamic data base used in different models but it is difficult to ascertain whether a certain difference has any effect on the final result unless the results are all compared. It should be emphasized, however, that any type of comparison will always be inadequate because any criterion that is chosen as a basis for comparison is usually not given the same priority by another model. For example, models that are developed for reaction path simulation may sacrifice computation efficiency on a species distribution calculation if more efficiency is gained in the reaction progress calculation. In this instance, as in many others, the computerized model is developed for a specific purpose and design priorities are assigned accordingly.

Each researcher was asked to complete a questionnaire describing the details of their program and to return the computed results on the two test cases. The responses received include representatives of most of the major aqueous models known. Table I identifies the programs and researchers who supplied the information for the particular program and includes general information on types of computers used, number of cards in the source deck, primary and secondary references and availability.

Table II gives a general description of the program features such as total number of elements, aqueous species, gases, organic species, redox species, solid species, pressure and temperature ranges over which calculations can be made, an indication of the types of equations used for computing activity coefficients, numerical method used for calculating distribution of species and the total number of iterations required by these models for each of the two test cases. The chemical analyses for the two test cases are summarized in Table III. The seawater compilation was prepared in several units to assure consistency between concentrations for proper entry into the aqueous models.

The results of the river water and seawater test cases computed by the aqueous models listed in Table I are summarized in Tables IV-X. Tables IV and V compare selected major and minor species computed for the river water test case, and Tables VI and VII make a similar comparison for the seawater test case. Table VIII compares activity coefficients computed for the major species in seawater and Table IX and $X$ tabulate saturation indices for selected minerals in the river water and seawater test 
cases. The saturation index, SI, is defined as $\log$ IAP/Ksp where IAP is the ion activity product for the mineral and Ksp is the thermodynamic solubility product constant.

\section{Discussion}

The remainder of this paper is a plea for caution and restraint in interpreting the results of the test cases shown here, and in the use of computerized chemical models in general. Tables IV $X$ show both remarkable agreement and disagreement. In general, there is better agreement between the major species concentrations than the minors and the results for the river water tend to agree better than those for seawater. We would expect better agreement in the river water test case because of the smaller amount of complexing in the more dilute solution and the more consistent and reliable activity coefficients which can be obtained at low ionic strength.

There are several limitations which lead to the discrepancies in Tables IV-X. First of all, no model will be better than the assumptions upon which it is based. The models compiled in this survey are based on the ion association approach whose general reliability rests on several non-thermodynamic assumptions. For example, the use of activity coefficients to describe the non-ideal behavior of aqueous electrolytes reflects our uncertain knowledge of ionic interactions and as a consequence we must approximate activity coefficients with semiempirical equations. In addition, the assumption of ion association may be a naive representation of the true interactions of "ions" in aqueous solutions. If a consistent and comprehensive theory of electrolyte solutions were available along with a consistent set of thermodynamic data then our aqueous models should be in excellent agreement for most systems. Until such a theory is provided we should expect the type of results shown in Tables IV-X. No degree of computational or numerical sophistication can improve upon the basic chemical model which is utilized.

The second limitation, almost a corollary of the first, is the reliability of the equilibrium constants (or free energies) used in the model. It is quite common for solubility product constants and complex stability constants to vary by 1 to 3 orders of magnitude and have been observed to vary by that much in these models. Quite clearly this amount of uncertainty can cause large differences in the computed results and probably contributes the largest single source of error. The thermodynamic properties of substances are currently in a state of refinement by many researchers and continual updating of the aqueous models is needed. This situation is quite frustating for investigators who are involved in solute transport modeling since they need a general chemical model with a fixed data base. An internally consistent data base can be obtained 
Table I

General Information

\begin{tabular}{|c|c|c|c|c|c|c|c|c|c|c|c|c|c|c|}
\hline $\begin{array}{c}\text { Program } \\
\text { Name }\end{array}$ & EQUIL & EQ3 & GEOCHEM & IONPAIR & MINEQL2 & MIRE & $\begin{array}{l}\text { MINEQL/ } \\
\text { REDEQL2 }\end{array}$ & REDEQL2 & SEAWAT & SOLMNEQ & WATEQF & WATEQ2 & WATSPEC & $\begin{array}{l}\text { SIAS/ } \\
\text { COMICS }\end{array}$ \\
\hline Language & FORTRAN & FORTRAN & FORTRAN & FORTRAN & FORTRAN & FORTRAN & FORTRAN & FORTRAN & FORTRAN & $\mathrm{PL} / 1$ & FORTRAN & $\begin{array}{c}\mathrm{PL} / 1 \\
\text { (optimizing) }\end{array}$ & FORTRAN & FORTRAN \\
\hline Computers & $\begin{array}{l}\text { UNIVAC } \\
1110\end{array}$ & $\begin{array}{c}\operatorname{CDC} \\
6400 / 6600 \\
7600\end{array}$ & $\begin{array}{c}\text { IBM } \\
360 / 50\end{array}$ & $\begin{array}{l}\text { IBM } \\
370 / \\
16511\end{array}$ & $\begin{array}{c}\text { CDC } \\
\text { CYBER } \\
74\end{array}$ & IBM 360 & IBM 370 & $\begin{array}{c}\text { COC } \\
\text { CYBER } \\
74\end{array}$ & $\begin{array}{ll}\text { CDC } & 6400 \\
\text { IBM } & 360 \\
\text { IBM } & 370 \\
\text { IBM } & 7094 \\
\text { IDEC } & 10\end{array}$ & IBM 370 & IBM 3701 & $\begin{array}{l}\text { IBM 37u } \\
\text { Honeywe11 } \\
60 / 68 / 80\end{array}$ & $\begin{array}{l}\text { ICL } 1903 \\
\text { IBM } \\
370\end{array}$ & IBM 360 \\
\hline $\begin{array}{l}\text { Number of } \\
\text { Cards }\end{array}$ & 3300 & 3048 & 3630 & 606 & 1500 & 420 & 1500 & 4000 & 184 & 2000 & 1857 & 3000 & 423 & 253 \\
\hline $\begin{array}{l}\text { Primary } \\
\text { Reference ( } s)\end{array}$ & (32) & (37) & $(\underline{50)}$ & (47) & $(\underline{60})$ & (46) & $(\underline{50)}$ & $(\underline{50)}$ & $(\underline{45})$ & (36) & $(\underline{34}, \underline{35})$ & $(\underline{34}, \underline{35})$ & (41) & (25) \\
\hline $\begin{array}{l}\text { Secondary } \\
\text { Reference (s) }\end{array}$ & (33) & $(\underline{43}, \underline{44})$ & (85) & $(\underline{87}, \underline{88})$ & (85) & (86) & (ㄷ) & (마) & & & (38) & $(\underline{40)}$ & (42) & (26) \\
\hline $\begin{array}{l}\text { Available } 2 \\
\text { From }\end{array}$ & B. Fritz* & \begin{tabular}{|l} 
T.J. \\
Wolery*
\end{tabular} & $\begin{array}{l}\text { S.v. } \\
\text { Matti god } \\
\text { G. } \\
\text { Sposito* }\end{array}$ & $\begin{array}{l}\text { J. } \\
\text { Thrail- } \\
\text { ki11* }\end{array}$ & $\begin{array}{l}\text { M.R. } \\
\text { Hoff- } \\
\text { mann* }\end{array}$ & $\begin{array}{l}\text { G.R. } \\
\text { Holdren } \\
\text { Jr.* }\end{array}$ & $\begin{array}{l}\text { F.M.M. } \\
\text { Morel } \\
\text { R.E. } \\
\text { McDuff }\end{array}$ & $\begin{array}{l}\text { M.R. } \\
\text { Hoff- } \\
\text { man* }\end{array}$ & $\begin{array}{l}\text { G.M. } \\
\text { Lafon* }\end{array}$ & $\begin{array}{l}\text { R.L. } \\
\text { Bassett } \\
\text { Y.K. } \\
\text { Kharaka }\end{array}$ & $\begin{array}{l}\text { L. N. } \\
\text { Piummer* }\end{array}$ & $\begin{array}{l}\text { J.W. } \\
\text { Bali* } \\
\text { E.A. } \\
\text { Jenne* }\end{array}$ & $\begin{array}{l}\text { Geo } \\
\text { Ab- } \\
\text { stracts }{ }^{4}\end{array}$ & \begin{tabular}{|c|} 
T. M. \\
Florence*
\end{tabular} \\
\hline
\end{tabular}

$1_{\text {WATEOF }}$ is also available for use on an UNIVAC 1110 computer by contacting M.M. Reddy. 2Coauthors who contributed data given in this and subsequent tables are identified by an asterisk, $\star$ 3U.S. Geological Survey, 345 Middlefield Road, Menlo Park, CA 94025 . 4Geo Abstracts Limited, University of East Anglia, Norwich NR4 7TJ, England; price \$1.70. WATSPEC calculations on subsequent tables were contributed by T.M.L. Wigley. 
Table II

Descriptive Program Features

\begin{tabular}{|c|c|c|c|c|c|c|c|c|c|c|c|c|c|c|}
\hline $\begin{array}{l}\text { Program } \\
\text { Name }\end{array}$ & EQUIL & EQ3 & GEOCHEM & IONPAIR & MINEQL2 & MIRE & $\begin{array}{l}\text { MINEQL/ } \\
\text { REDEQL2 }\end{array}$ & REDEQL 2 & SEAWAT & SOLMNEQ & WATEQF & WATEQ2 & WATSPEC & $\begin{array}{l}\text { SIAS/ } \\
\text { COMICS }\end{array}$ \\
\hline Elements 1 & 20 & 18 & 44 & 8 & 38 & 11 & * & 44 & 7 & 24 & 19 & 29 & 16 & * \\
\hline Aqueous Sp. & 93 & 140 & 2000 & 26 & * & 49 & * & 266 & 23 & 181 & 105 & 220 & 69 & * \\
\hline Gases & 3 & 8 & 2 & 1 & * & 0 & * & 2 & 1 & 3 & 3 & 3 & 2 & * \\
\hline Organics & 0 & 0 & 889 & 0 & * & 1 & * & 35 & 0 & 10 & 0 & 12 & 0 & * \\
\hline Redox Sp. & 9 & 14 & 20 & 0 & * & 0 & * & 24 & 0 & 12 & 8 & 12 & 6 & * \\
\hline Minerals & 120 & 130 & 185 & 5 & * & variable & * & 154 & variable & 158 & 101 & 309 & 40 & * \\
\hline $\begin{array}{l}\text { Activity } \\
\text { Coefficients } 2\end{array}$ & 2 B-dot & B-dot & $\begin{array}{l}\text { Davies } \\
\text { or B-dot }\end{array}$ & EDH & Davies & EDH & Davies & Davies & B-dot & B-dot & $\begin{array}{l}\text { B-dot or } \\
\text { Davies }\end{array}$ & $\begin{array}{l}\text { B-dot or } \\
\text { Davies }\end{array}$ & $\begin{array}{l}\text { B-dot or } \\
\text { Davies }\end{array}$ & $\star \star$ \\
\hline $\begin{array}{l}\text { Temperature } \\
\text { Range }{ }^{\circ} \mathrm{C}\end{array}$ & $0-300$ & $0-300$ & 25 & $0-25$ & 25 & 25 & 25 & 25 & $0-100$ & $0-350$ & $0-100$ & $0-100$ & $0-100$ & 25 \\
\hline $\begin{array}{l}\text { Pressure } \\
\text { range } \\
\text { bars }\end{array}$ & 1 & $\begin{array}{l}\text { to steam } \\
\text { satura- } \\
\text { tion or } \\
500 \text { bars }\end{array}$ & 1 & 1 & 1 & 1 & 1 & 1 & $1-1000$ & $1-1000$ & 1 & 1 & 1 & 1 \\
\hline $\begin{array}{l}\text { Iteration } \\
\text { and con- } \\
\text { vergence } \\
\text { method }\end{array}$ & $\begin{array}{l}\text { explicit } \\
\text { equations }\end{array}$ & $\begin{array}{l}\text { Monotone } \\
\text { sequences } \\
\text { and secant } \\
\text { method }\end{array}$ & $\begin{array}{l}\text { Newton- } \\
\text { Raphson }\end{array}$ & $\begin{array}{l}\text { Free ion } \\
\text { molali- } \\
\text { ties by } \\
\text { difference }\end{array}$ & $\begin{array}{l}\text { Newton- } \\
\text { Raphson }\end{array}$ & $\begin{array}{l}\text { continued } \\
\text { fraction }\end{array}$ & $\begin{array}{l}\text { Newton- } \\
\text { Raphson }\end{array}$ & $\begin{array}{l}\text { Newton- } \\
\text { Raphson }\end{array}$ & $\begin{array}{l}\text { continued } \\
\text { fraction }\end{array}$ & $\begin{array}{l}\text { continued } \\
\text { fraction } \\
\text { for anions } \\
\text { only }\end{array}$ & $\begin{array}{l}\text { continued } \\
\text { fraction }\end{array}$ & $\begin{array}{l}\text { continued } \\
\text { fraction }\end{array}$ & $\begin{array}{l}\text { continued } \\
\text { fraction }\end{array}$ & $\begin{array}{l}\text { brute } \\
\text { force }\end{array}$ \\
\hline Fresh Water ${ }^{3}$ & $<10$ & 5 & - & 7 & $\dagger$ & 3 & $\dagger$ & $32^{\dagger}$ & - & 7 & 1 & 2 & 1 & $\dagger$ \\
\hline Seawater ${ }^{3}$ & $<30$ & 6 & 156 & - & $t$ & 5 & + & $57^{\dagger}$ & 4 & 11 & 4 & 4 & 5 & 29 \\
\hline
\end{tabular}

lexcluding those of water. 2EDH - extended Debye Huckel, B-dot - extended Debye Huckel with added B ${ }^{\circ}$ I term, Davies - Davies equation.

3 Number of iterations where one iteration is defined as one pass through the mass action equations of the aqueous model. ${ }^{*}$ depends on data base.

**Constant ionic medium. tdepends on initial guess by user. 
Table III

Test Case Data

River Water

\begin{tabular}{|c|c|}
\hline pecies & $\mathrm{mg} / 1$ \\
\hline $\mathrm{Na}$ & 12. \\
\hline $\mathrm{K}$ & 1.4 \\
\hline $\mathrm{Ca}$ & 12.2 \\
\hline Mg & 7.5 \\
\hline Si & 8.52 \\
\hline $\mathrm{HCO}_{3}^{-\star \star}$ & 75.2 \\
\hline $\mathrm{Cl}$ & 9.9 \\
\hline $\mathrm{SO}_{4}$ & 7. \\
\hline $\mathrm{Br}$ & 0.006 \\
\hline I & 0.0018 \\
\hline $\mathrm{F}$ & 0.10 \\
\hline $\mathrm{PO}_{4}$ & 0.210 \\
\hline $\mathrm{NO}_{3}^{4}$ & 0.898 \\
\hline $\mathrm{NO}_{2}^{3}$ & 0.019 \\
\hline $\mathrm{NH}_{4}^{2}$ & 0.144 \\
\hline 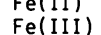 & $\begin{array}{l}0.015 \\
0.0007\end{array}$ \\
\hline $\mathrm{Mn}$ & 0.0044 \\
\hline Al & 0.005 \\
\hline $\mathrm{Zn}$ & \\
\hline$c d$ & 0.0001 \\
\hline $\mathrm{Hg}$ & 0.0000 \\
\hline $\mathrm{Pb}$ & \\
\hline $\mathrm{Cu}$ & \\
\hline Co & \\
\hline $\mathrm{Ni}$ & 0.0018 \\
\hline $\mathrm{Cr}$ & 0.0 \\
\hline $\mathrm{Ag}$ & 0.0 \\
\hline Mo & 0.0005 \\
\hline & 0.002 \\
\hline $\mathrm{H}_{2} \mathrm{~S}$ & 0.002 \\
\hline & 10.94 \\
\hline Eh (V) & 0.440 \\
\hline & 2.5 \\
\hline & \\
\hline pH & \\
\hline Density & 1.00 \\
\hline
\end{tabular}

Seawater ${ }^{\star}$

\begin{tabular}{|c|c|c|c|c|c|}
\hline species & $\mathrm{mg} / \mathrm{kg}$ soln & $\mathrm{mmol} / \mathrm{kg} \mathrm{H} \mathrm{H}_{2} \mathrm{O}$ & $\mathrm{mmol} / 1$ & $\mathrm{mg} / 1$ & GFW \\
\hline $\mathrm{Ca}$ & $\begin{array}{r}412.3 \\
1291\end{array}$ & 10.6617 & 10.5272 & 421.931 & 40.08 \\
\hline $\mathrm{Mg}$ & 1291.8 & $\begin{array}{r}55.08565 \\
485.4435\end{array}$ & $\begin{array}{r}54.39113 \\
479.3230\end{array}$ & $\begin{array}{l}1321.976 \\
11019.54\end{array}$ & $\begin{array}{l}24.305 \\
22.9898\end{array}$ \\
\hline $\mathrm{K}$ & 399.1 & $\begin{array}{r}485.4435 \\
10.5794\end{array}$ & 10.4461 & 408.423 & 39.0983 \\
\hline $\mathrm{Cl}$ & 19353. & 565.7625 & 558.6293 & 19805.09 & 35.453 \\
\hline $\mathrm{SO}_{4}$ & 2712 . & 29.2615 & 28.8926 & 2775.35 & 96.0576 \\
\hline Alkal. † & 141.682 & 2.40659 & 2.37625 & 144.992 & 61.0171 \\
\hline & 67.3 & 0.87294 & 0.86194 & 68.872 & 79.904 \\
\hline $\mathrm{Sr}$ & 8.14 & 0.096285 & 0.095071 & 8.3302 & 87.62 \\
\hline $\begin{array}{l}\text { B } \\
\text { SiO }\end{array}$ & $\begin{array}{l}4.45 \\
4.28\end{array}$ & $\begin{array}{l}0.42665 \\
0.073828\end{array}$ & $\begin{array}{l}0.42127 \\
0.072897\end{array}$ & $\begin{array}{l}4.5540 \\
4.3800\end{array}$ & $\begin{array}{l}10.81 \\
60.0843\end{array}$ \\
\hline $\mathrm{F}$ & $\begin{array}{l}4.28 \\
1.39\end{array}$ & 0.075829 & 0.074873 & $\begin{array}{l}4.5000 \\
1.4225\end{array}$ & 18.9984 \\
\hline $\mathrm{Ba}$ & 0.02 & 0.000151 & 0.000149 & 0.0205 & 137.33 \\
\hline I & 0.062 & 0.0005064 & 0.0005000 & 0.06345 & 126.9045 \\
\hline $\mathrm{PO}_{4}$ & 0.06 & 0.000655 & 0.000647 & 0.0614 & 94.9714 \\
\hline $\mathrm{NO}_{3}^{4}$ & 0.29 & 0.004847 & 0.004786 & 0.2968 & 62.0049 \\
\hline $\mathrm{NO}^{3}$ & 0.02 & 0.000451 & 0.000445 & 0.0205 & 46.0055 \\
\hline $\mathrm{NH}_{4}^{2}$ & 0.03 & 0.0 & 0.00170 & 0.0307 & 18.0383 \\
\hline $\mathrm{Fe}^{4}$ & 0.002 & 0.0000371 & 0.0000366 & 0.00205 & 55.847 \\
\hline $\mathrm{Mn}$ & 0.0002 & 0.00000377 & 0.00000373 & 0.000205 & 54.9380 \\
\hline Al & 0.002 & 30768 & 0.0000759 & 0.00205 & 26.9815 \\
\hline $\mathrm{Zn}$ & 0.0049 & 0.00007768 & 0.00007670 & 0.005014 & 65.38 \\
\hline $\mathrm{Cd}$ & 0.0001 & 0.000000922 & 0.000000910 & 0.000102 & 112.41 \\
\hline $\mathrm{Hg}$ & 0.00003 & 1000155 & 0.000000153 & 0.0000307 & 200.59 \\
\hline $\mathrm{Pb}$ & 005 & 000250 & 0.000000247 & 0.0000512 & 207.2 \\
\hline $\mathrm{Cu}$ & 0.0007 & 0114 & 0.0000112 & 0.000716 & 63.546 \\
\hline Co & 0.00005 & 000879 & 0.000000868 & 0.0000512 & 58.9332 \\
\hline $\mathrm{Ni}$ & 0.00 & 02056 & 0.00002030 & 0.001740 & \\
\hline $\mathrm{Cr}$ & 0.0003 & 0.00000598 & 0.00000590 & 0.000307 & 51.996 \\
\hline $\mathrm{Ag}$ & 0.00004 & 000384 & 0.000000379 & 0.0000409 & 107.868 \\
\hline $\mathrm{Sb}$ & 0.00033 & 0.000002809 & 0.000002774 & 0.0003377 & 121.75 \\
\hline Mo & 0.0 & 0.0000540 & 0.0000533 & & 95.94 \\
\hline As & 0.004 & 0.0000553 & 0.0000546 & 0.000409 & 74.9216 \\
\hline $\mathrm{Li}$ & 0.181 & 0.027027 & 0.026686 & 0.18523 & 6.941 \\
\hline $\mathrm{Rb}$ & 0.117 & 0.0014188 & 0.0014009 & 0.11973 & 85.4678 \\
\hline Cs & 0.0004 & 0.00000312 & 0.00000318 & 0.00409 & 132.9054 \\
\hline $\begin{array}{l}\text { D0 } \\
\text { Eh (V) }\end{array}$ & & & & & \\
\hline & & & & & \\
\hline & & & & & \\
\hline Den & & & & & \\
\hline
\end{tabular}

*Original data are in ppm, except total titration alkalinity which is $2.322 \mathrm{meq} / \mathrm{kg} \mathrm{soln}$. All other units have been derived from these values using: density $=g / c c$, salinity $=35 . \%$, $\mathrm{kg} \mathrm{soln} / \mathrm{kgH} 0=$ 1.03642731 , and the values of Gram Formula Weight given. The derived units are given to two additional

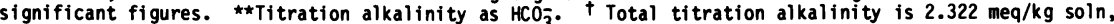
expressed here as $\mathrm{HCO}_{3}^{-}$. The total titration alkalinity includes carbonate as well as non-carbonate alkalinity. Instead of total alkafinity, the input may be expressed as total inorganic carbon which is $2.022 \mathrm{mmol} / \mathrm{kg} \mathrm{soln}$, or $123.377 \mathrm{ppm}, 126.259 \mathrm{mg} / 1,2.06924 \mathrm{mmol} / 1,2.09566 \mathrm{mmol} / \mathrm{kgH}_{2} \mathrm{O}^{2}$, as $\mathrm{HCO}_{3}^{-}$. Al ternatively total inorganic carbon may be expressed as $\mathrm{H}_{2} \mathrm{CO}_{3}^{\star}\left(\mathrm{H}_{2} \mathrm{CO}_{3}^{\star}=\mathrm{H}_{2} \mathrm{CO}_{3}^{\circ}+\mathrm{CO}_{2}^{\circ}\right)+\mathrm{HCO}_{3}^{-}($totaf $)+\mathrm{CO}-($ total $)$. In this case, $\mathrm{H}_{2} \mathrm{CO}_{3}^{\star}$ is

$0.742030 \mathrm{ppm}, 0.759364 \mathrm{mg} / 1,0.0122429 \mathrm{mmol} / 1,0.0123992 \mathrm{mmol} / \mathrm{kgH}_{2}$; $\mathrm{HCO}_{3}$ (total) is $109.469 \mathrm{pFm}$,

$112.026 \mathrm{mg} / 1,1.83598 \mathrm{mmol} / \mathrm{l}, 1.85942 \mathrm{~mol} / \mathrm{kgH}_{2} 0$; and $\mathrm{CO}_{3}-(\text { total })^{2}$ is $12.9598 \mathrm{ppm}, 13.2625 \mathrm{mg} / 1$,

$0.221228 \mathrm{mmol} / 1,0.223831 \mathrm{~mol} / \mathrm{kgH}_{2} \mathrm{O}$.

Jenne; Chemical Modeling in Aqueous Systems ACS Symposium Series; American Chemical Society: Washington, DC, 1979. 
Downloaded by CALIFORNIA INST OF TECHNOLOGY on May 23, 2017 | http://pubs.acs.org

Publication Date: March 19, 1979| doi: 10.1021/bk-1979-0093.ch038

Table IV, $p(m),-L o g$ Molality, of Selected Major Species in River Water Test Case

\begin{tabular}{|c|c|c|c|c|c|c|c|c|c|c|c|}
\hline PROGRAM & EQUIL & EQ3 & IONPAIR & MINEQL2* & MIRE & $\begin{array}{l}\text { MINEQL/ } \\
\text { REDEQL2 }\end{array}$ & REDEQL2 & SOLMNEQ & WATEQF & WATEU2 & WAT SPEC \\
\hline $\mathrm{Ca}^{2+}$ & 3.532 & 3.529 & 3.522 & $3.54^{\dagger}$ & 3.530 & $3.54^{\dagger}$ & 3.539 & 3.527 & 3.525 & 3.525 & 3.525 \\
\hline $\mathrm{CaSO}_{4}^{\circ}$ & 5.537 & 5.578 & 5.6 & $5.58^{\dagger}$ & 5.533 & $5.55^{\dagger}$ & 5.58 & 5.545 & 5.578 & 5.577 & b.545 \\
\hline $\mathrm{CaHCO}_{3}^{+}$ & 5.288 & 5.343 & - & $5.17^{\dagger}$ & 5.409 & $5.22^{\dagger}$ & 5.27 & 5.518 & 5.722 & 5.723 & b.714 \\
\hline $\mathrm{CaCO}_{3}^{\circ}$ & 5.681 & 5.933 & 6. & $5.76^{\dagger}$ & 5.732 & $5.82^{\dagger}$ & 5.27 & 5.959 & 6.000 & 6.001 & 5.992 \\
\hline $\mathrm{Mg}^{2+}$ & 3.523 & 3.519 & 3.518 & 3.53 & 3.521 & 3.54 & 3.53 & 3.519 & 3.519 & 3.519 & 3.520 \\
\hline $\mathrm{MgSO}_{4}^{\circ}$ & 5.586 & 5.750 & 5.7 & 5.47 & 5.593 & 5.45 & 5.47 & 5.726 & 5.767 & 5.756 & 5.600 \\
\hline $\mathrm{MgHCO}_{3}^{+}$ & 5.636 & 5.491 & 5.6 & 5.16 & 5.568 & 5.21 & 5.25 & 6.027 & 5.495 & 5.496 & 5.486 \\
\hline $\mathrm{MgCO}_{3}^{\circ}$ & 5.470 & 6.133 & 6. & 5.55 & 5.988 & 5.61 & 5.65 & 5.622 & 6.156 & 6.157 & 6.147 \\
\hline $\mathrm{Na}^{+}$ & 3.283 & 3.282 & 3.283 & 3.28 & 3.284 & 3.28 & 3.28 & 3.283 & 3.283 & 3.283 & 3.283 \\
\hline $\mathrm{NaSO}_{4}^{-}$ & 6.447 & 6.819 & 7. & 6.82 & 7.280 & 6.81 & 6.82 & 6.617 & 6.819 & 6.820 & 6.793 \\
\hline $\mathrm{NaHCO}_{3}^{\circ}$ & 6.505 & - & - & - & 6.500 & - & - & 6.496 & 6.495 & 6.496 & 0.494 \\
\hline $\mathrm{K}^{+}$ & 4.446 & 4.446 & 4.45 & 4.45 & 4.444 & 4.45 & 4.45 & 4.446 & 4.446 & 4.446 & 4.446 \\
\hline $\mathrm{KSO}_{4}^{-}$ & 7.830 & 7.896 & - & 7.59 & 7.819 & 7.58 & 7.60 & 7.942 & 7.935 & 7.936 & 7.910 \\
\hline $\mathrm{SO}_{4}^{2-}$ & 4.129 & 4.122 & 4.12 & 4.14 & 4.128 & 4.15 & 4.14 & 4.122 & 4.121 & 4.121 & 4.164 \\
\hline $\mathrm{Cl}^{-}$ & 3.401 & 3.554 & 3.554 & 3.55 & 3.556 & 3.55 & 3.55 & 3.558 & 3.554 & 3.554 & 3.554 \\
\hline $\mathrm{HCO}_{3}^{-}$ & 2.924 & 2.920 & 2.915 & 2.93 & 2.919 & 2.91 & 2.93 & 2.918 & 2.917 & 2.917 & 2.917 \\
\hline $\mathrm{CO}_{3}^{2-}$ & 5.164 & 5.346 & 5.3 & 5.01 & 5.168 & 5.11 & 5.12 & 5.328 & 5.334 & 5.333 & 5.333 \\
\hline $\mathrm{B}(\mathrm{OH})_{3}^{\circ}$ & 5.361 & - & - & 5.37 & - & - & - & 5.379 & 5.354 & 5.355 & 5.355 \\
\hline $\mathrm{B}(\mathrm{OH})_{\overline{4}}$ & 6.570 & - & - & 6.41 & - & - & 6.42 & 6.726 & 6.690 & 6.711 & 6.688 \\
\hline $\mathrm{Br}^{-}$ & - & - & - & 7.12 & - & - & 7.12 & - & 7.124 & 7.124 & 7.120 \\
\hline$F^{-}$ & 5.281 & - & - & 5.29 & - & - & 5.29 & 5.282 & 5.284 & 5.284 & - \\
\hline $\mathrm{H}_{4} \mathrm{SiO}_{4}^{\circ}$ & 3.528 & - & - & $3.53^{\dagger}$ & - & - & $3.53^{\dagger}$ & 3.523 & 3.851 & 3.520 & 3.520 \\
\hline $\mathrm{H}^{+}$ & 7.988 & 7.989 & - & - & - & 8.01 & - & 7.990 & 7.987 & 7.987 & 7.987 \\
\hline $\mathrm{OH}^{-}$ & 5.966 & 6.518 & 6. & 5.94 & 5.967 & - & 5.95 & 6.525 & 6.502 & 6.501 & 6.502 \\
\hline $\begin{array}{l}\text { Ionic } \\
\text { Strength }\end{array}$ & .00238 & .00239 & .00240 & .00300 & .0024 & - & .00300 & .00240 & .00240 & .00241 & .00239 \\
\hline
\end{tabular}

$\mathrm{Fe}, \mathrm{Al}$ and Si species are not exactly comparable to the same species from the other programs because of this equilibrium prJcess and, of course, all

species have been affected to some degree. 
Table $V$

$p(m)$, - Log Molality, of Selected Minor Species in River Water Test Case

$\begin{array}{lcccccccccc}\text { PROGRAM } & \text { EQUIL } & \text { EQ3 } & \text { IONPAIR } & \text { MINEQL2 } & \text { MIRE } & \text { REDEQL2 } & \text { SOLMNEQ } & \text { WATEQF } & \text { WATEQ2 } & \text { WATSPEC } \\ \mathrm{Cr}^{3+} & - & - & - & 20.02 & - & 16.15 & - & - & - & - \\ \mathrm{Mn}^{2+} & 7.100 & 8.205 & - & 7.14 & 7.138 & 7.13 & 7.099 & 7.119 & 7.119 & - \\ \mathrm{MnOH}^{+} & - & 11.403 & - & 9.28 & 9.804 & 9.28 & - & 10.264 & 10.347 & - \\ \mathrm{MnSO}_{4}^{\circ} & 9.166 & 10.383 & - & 9.18 & 9.213 & 9.18 & 9.289 & 9.864 & 9.864 & - \\ \mathrm{Fe}^{2+} & 6.711 & 6.639 & - & 15.18^{\dagger} & 6.896 & 15.18^{\dagger} & 8.389 & 12.167 & 6.579 & 11.953 \\ \mathrm{FeOH}^{+} & 7.075 & 7.428 & - & 15.82^{\dagger} & 6.855 & 15.83^{\dagger} & 26.711 & 14.257 & 8.669 & 13.860 \\ \mathrm{Fe}^{3+} & 19.04 & 16.212 & - & 20.88^{\dagger} & - & 20.640^{\dagger} & 25.811 & 17.635 & 18.596 & 17.408 \\ \mathrm{Fe}^{+} \mathrm{OH}_{4}^{-} & - & 8.072 & - & 10.44^{\dagger} & - & 10.35^{\dagger} & 18.172 & 6.989 & 8.340 & 7.028 \\ \mathrm{Ni}^{2+} & - & - & - & 7.59 & - & 7.93 & - & - & 8.892 & - \\ \mathrm{NiCO}_{3}^{\circ} & - & - & - & - & - & 7.76 & - & - & 7.539 & - \\ \mathrm{Cu}^{2+} & 10.15 & 8.763 & - & 9.67 & - & 10.42 & 14.772 & - & 11.293 & - \\ \mathrm{Cu}^{2+} \mathrm{OH}_{2}^{\circ} & - & - & - & 13.68 & - & 13.22 & - & - & 9.045 & - \\ \mathrm{Ag}^{+} & - & 9.660 & - & - & - & 15.51 & 9.651 & - & 15.891 & - \\ \mathrm{AgHS}^{\circ} & - & - & - & - & - & - & - & - & 9.432 & - \\ \mathrm{Zn}^{2+} & 8.131 & 8.129 & - & 8.15 & - & 8.48 & 7.129 & - & 8.504 & - \\ \mathrm{ZnCO}_{3}^{\circ} & - & - & - & - & - & 8.51 & - & - & 8.720 & - \\ \mathrm{Zn}^{+} \mathrm{HS}_{2}^{\circ} & - & - & - & - & - & - & - & - & 8.790 \\ \mathrm{Cd}^{2+} & - & - & - & 9.10 & - & 9.41 & - & - & 11.612 & - \\ \mathrm{CdOH}^{+} & - & - & - & 10.15 & - & 11.46 & - & - & 12.651 & -\end{array}$




\begin{tabular}{|c|c|c|c|c|c|c|c|c|c|c|c|}
\hline $\mathrm{CdHS}^{+}$ & - & - & - & - & - & - & - & - & 9.078 & - & \\
\hline $\mathrm{Hg}^{2+}$ & - & 16.875 & - & 21.07 & - & 20.15 & 41.872 & - & - & - & \\
\hline $\mathrm{Al}^{3+}$ & 15.69 & 13.697 & - & $17.49^{\dagger}$ & - & $17.164^{\dagger}$ & 13.598 & 13.908 & 15.565 & 14.778 & \\
\hline $\mathrm{Al}(\mathrm{OH})_{\overline{4}}$ & 7.090 & 6.732 & - & 8.66 & - & $8.37^{\dagger}$ & 6.765 & 6.741 & 8.406 & 6.733 & \\
\hline $\mathrm{Pb}^{2+}$ & 9.845 & 14.380 & - & 12.07 & - & 11.93 & 9.843 & - & 11.749 & - & \\
\hline $\mathrm{PbOH}^{+}$ & - & - & - & 11.21 & - & 11.68 & - & - & 10.378 & - & \\
\hline $\mathrm{PbCO}_{3}^{\circ}$ & - & 9.839 & - & 9.89 & - & 9.86 & - & - & 10.025 & - & \\
\hline $\mathrm{NO}_{3}^{-}$ & 4.839 & - & 4.84 & - & - & - & 4.839 & 4.839 & 4.839 & 4.839 & \\
\hline $\mathrm{NH}^{+}$ & 5.098 & - & - & 5.14 & - & 5.13 & 5.105 & 5.106 & 5.106 & 10.392 & \\
\hline $\mathrm{PO}_{4}^{3-}$ & 10.03 & - & - & $11.41^{\dagger}$ & - & $11.40^{\dagger}$ & 10.189 & 10.156 & 10.156 & - & \\
\hline $\mathrm{HPO}_{4}^{2-}$ & 5.818 & - & - & $7.07^{\dagger}$ & 5.773 & $7.16^{\dagger}$ & 5.813 & 5.793 & 5.793 & - & \\
\hline $\mathrm{H}_{2} \mathrm{PO}_{4}^{-}$ & 6.694 & - & - & $7.78^{\dagger}$ & 6.654 & $8.06^{\dagger}$ & 6.622 & 6.625 & 6.625 & - & \\
\hline $\mathrm{HAsO}_{4}^{2-}$ & - & - & - & - & - & - & 13.990 & - & 7.595 & - & \\
\hline $\mathrm{H}_{2} \mathrm{As}_{4}^{-}$ & - & - & - & - & - & - & 15.046 & - & 8.885 & - & \\
\hline$s^{2-}$ & - & 17.140 & - & - & - & - & 16.489 & 12.613 & 12.870 & 12.615 & \\
\hline $\mathrm{HS}^{-}$ & - & 7.268 & - & - & - & - & 7.299 & 7.288 & 7.544 & 7.288 & \\
\hline $\mathrm{H}_{2} \mathrm{~S}^{\circ}$ & - & 8.076 & - & - & - & - & 8.071 & 8.146 & 8.403 & 8.146 & \\
\hline $\mathrm{I}^{-}$ & - & - & - & 7.785 & - & 7.86 & - & - & - & - & \\
\hline \multicolumn{12}{|c|}{$\begin{array}{l}\text { *Calculated at } 25^{\circ} \mathrm{C} \text {. } \text { TMINEQL2 and REDEQL2 results were calculated in such a way that the solution was equilibrated } \\
\text { with supersaturated phases. P, Ca, Fe, Al and Si species are not exactly comparable to the same species from the } \\
\text { other programs because of this equilibration process, and, of course, all species have been affected to some degree. }\end{array}$} \\
\hline
\end{tabular}


岕

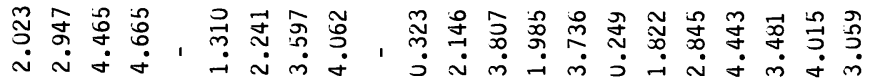

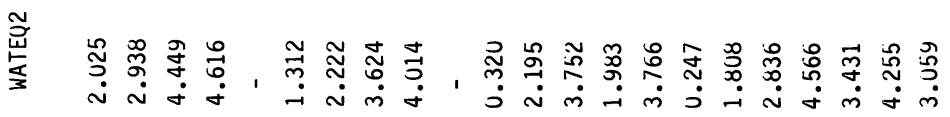

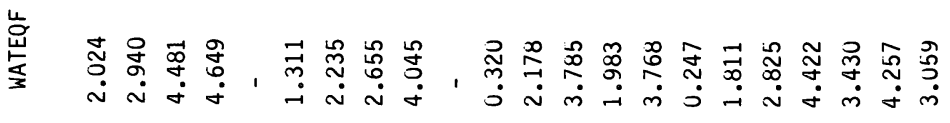

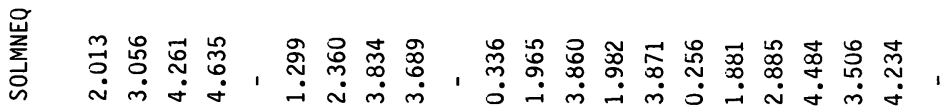

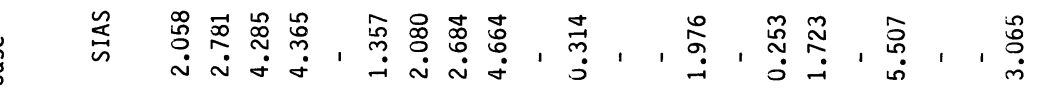

$\stackrel{\Delta}{\Delta} \quad$

紊

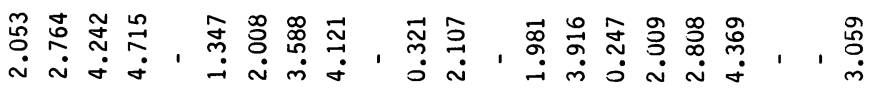

옴

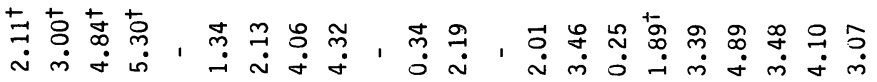

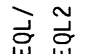

压㞻

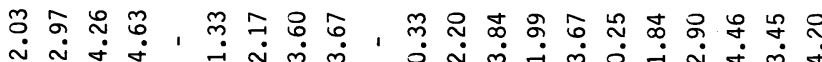

㟎

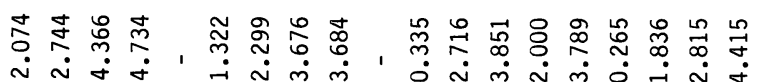

岂

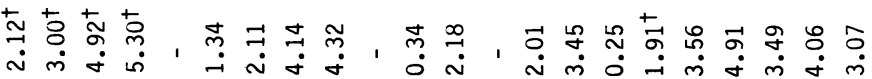

$\stackrel{k^{*}}{\stackrel{*}{+}}$

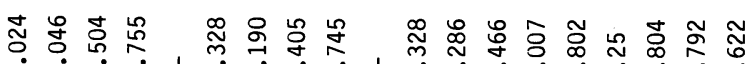

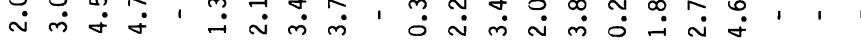

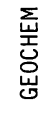

సี ๆ

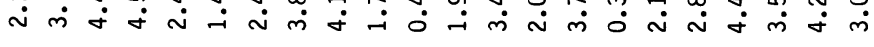

?̊.

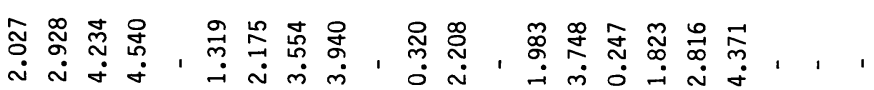

总

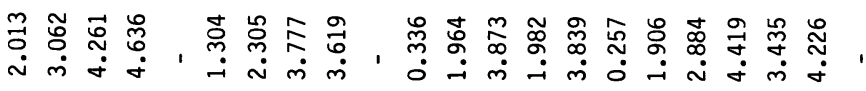

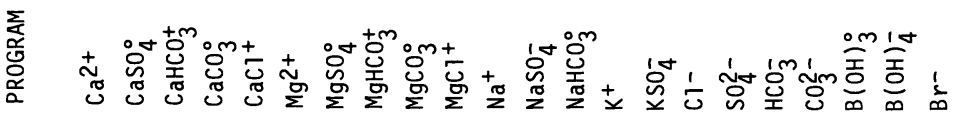

Jenne; Chemical Modeling in Aqueous Systems

ACS Symposium Series; American Chemical Society: Washington, DC, 1979. 


\begin{tabular}{|c|c|c|c|c|c|c|c|c|c|c|c|c|c|c|}
\hline$F^{-}$ & 4.228 & - & 4.36 & - & 4.39 & - & - & 4.38 & - & 4.411 & 4.379 & 4.410 & 4.410 & - \\
\hline $\mathrm{MgF}^{+}$ & 4.792 & - & 4.53 & - & 4.56 & - & - & 4.58 & - & - & 4.464 & 4.442 & 4.443 & - \\
\hline $\mathrm{Sr}^{2+}$ & 4.016 & - & 4.28 & - & $4.13^{\dagger}$ & - & - & $4.119^{\dagger}$ & - & - & 4.045 & 4.016 & 4.016 & 4.016 \\
\hline $\mathrm{H}_{4} \mathrm{SiO}_{4}^{\circ}$ & 4.155 & 4.159 & 4.16 & - & $4.19^{\dagger}$ & - & - & $4.17^{\dagger}$ & - & - & 4.161 & 4.145 & $4.14 b$ & 4.147 \\
\hline $\mathrm{H}^{+}$ & 8.125 & 8.126 & 8.15 & 7.966 & - & - & - & - & 8.095 & - & 8.125 & 8.093 & 8.093 & 8.098 \\
\hline $\mathrm{OH}^{-}$ & 5.603 & 5.606 & 5.65 & 6.038 & 5.46 & 5.552 & - & 5.54 & 5.613 & - & 5.601 & 5.660 & 5.660 & b.571 \\
\hline $\begin{array}{l}\text { Ionic } \\
\text { Strengh }\end{array}$ & 0.663 & 0.6772 & 0.5298 & - & 0.65 & 0.655 & - & 0.65 & 0.6595 & - & 0.6662 & 0.6801 & $0.679 y$ & 0.6770 \\
\hline
\end{tabular}

*Karpov and Kaz'min (1972) using Gibbs free energy minimization on a similar seawater. TMINEQL2 and REDEQL2 results were calculated in such a way that the solution was equilibrated with supersaturated phases. $\mathrm{Si}, \mathrm{Al}, \mathrm{Fe}, \mathrm{Ca}, \mathrm{Sr}, \mathrm{Ba}, \mathrm{Zn} \mathrm{SO}_{4}$, and $\mathrm{PO}_{4} \mathrm{Species}$ are not exactly comparable to the same species from the other programs because of this process, and, of course, ail species have been affected to some degree. 
Table VII

$p(m),-L o g$ Molality, of Selected Minor Species in Seawater Test Case

\begin{tabular}{|c|c|c|c|c|c|c|c|c|c|c|c|}
\hline PROGRAM & EQUIL & EQ3 & GEOCHEM & MINEQL2 & MIRE & REDEQL 2 & SIAS & SOLMNEQ & WATEQF & WATEQ2 & WATSPEC \\
\hline $\mathrm{Li}^{+}$ & 4.572 & - & 4.66 & - & - & - & - & 4.568 & 4.573 & 4.573 & 4.573 \\
\hline $\mathrm{Rb}^{+}$ & - & - & 5.87 & - & - & - & - & - & - & 5.848 & - \\
\hline $\mathrm{Cs}^{+}$ & - & - & 8.56 & - & - & - & - & - & - & 8.506 & - \\
\hline $\mathrm{Ba}^{2+}$ & - & - & 6.93 & $8.03^{\dagger}$ & - & $8.01^{\dagger}$ & - & 6.857 & 6.821 & 6.821 & 6.821 \\
\hline $\mathrm{Cr}^{3+}$ & - & - & 25.63 & 28.34 & - & 24.55 & - & - & - & - & - \\
\hline $\mathrm{Mn}^{2+}$ & 8.456 & 9.287 & 9.33 & 8.96 & 8.592 & 8.94 & - & 8.478 & 8.654 & 8.654 & - \\
\hline $\mathrm{MnCl}^{+}$ & - & - & 10.26 & 8.74 & 9.067 & 8.75 & - & 29.376 & 8.880 & 8.881 & - \\
\hline $\mathrm{Fe}^{3+}$ & 18.740 & 17.466 & 22.94 & $20.71^{\dagger}$ & - & $20.26^{\dagger}$ & - & - & 17.897 & 17.897 & 17.714 \\
\hline $\mathrm{Fe}(\mathrm{OH})_{3}^{\circ}$ & - & - & 11.28 & $17.10^{\dagger}$ & - & $24.14^{\dagger}$ & - & - & 8.071 & 8.071 & 7.805 \\
\hline $\mathrm{Fe}(\mathrm{OH}) \frac{-}{4}$ & - & 7.439 & 12.41 & $9.96^{\dagger}$ & - & $9.94^{\dagger}$ & - & - & 7.664 & 7.664 & 7.678 \\
\hline $\mathrm{Ni}^{2+}{ }^{4}$ & - & - & 9.23 & 7.77 & - & 7.92 & 7.834 & - & - & 8.813 & - \\
\hline $\mathrm{NiCl} \stackrel{\circ}{2}$ & - & - & 9.74 & - & - & 8.10 & - & - & - & 9.335 & - \\
\hline $\mathrm{NiCO}_{3}^{\circ}$ & - & - & 7.91 & 5.75 & - & 8.61 & - & - & - & 7.590 & - \\
\hline $\mathrm{Cu}^{2+}$ & 13.152 & 9.056 & 11.21 & 11.35 & - & 11.32 & 9.579 & - & - & 10.153 & - \\
\hline $\mathrm{Cu}(\mathrm{OH})_{3}^{\circ}$ & - & - & 12.40 & 3.22 & - & 9.06 & - & - & - & 7.985 & - \\
\hline $\mathrm{CuCO}_{3}^{\circ}$ & - & - & 10.01 & 10.82 & - & 10.80 & - & - & - & 9.070 & - \\
\hline $\mathrm{Ag}^{+}$ & - & 14.797 & 16.79 & 16.82 & - & 16.79 & - & 14.477 & - & 14.394 & - \\
\hline $\mathrm{AgCl}_{4}^{3-}$ & - & 9.517 & 12.48 & 12.08 & - & 12.05 & - & 9.617 & - & 9.684 & - \\
\hline $\mathrm{Zn}^{2+}$ & 7.323 & 7.346 & 8.35 & $7.74^{\dagger}$ & - & $8.06^{\dagger}$ & 7.690 & 7.321 & - & 7.547 & - \\
\hline $\mathrm{ZnCO}_{3}^{\circ}$ & - & - & 7.33 & - & - & $8.95^{\dagger}$ & - & - & - & 7.894 & - \\
\hline $\mathrm{Cd}^{2+}$ & - & - & 11.11 & 10.59 & - & 10.70 & 10.606 & - & - & 11.257 & - \\
\hline $\mathrm{CdCl}^{+}$ & - & - & 9.99 & 9.47 & - & 9.41 & - & - & - & 9.371 & - \\
\hline
\end{tabular}


Downloaded by CALIFORNIA INST OF TECHNOLOGY on May 23, 2017 | http://pubs.acs.org

Publication Date: March 19, 1979 | doi: 10.1021/bk-1979-0093.ch038

\begin{tabular}{|c|c|c|c|c|c|c|c|c|c|c|c|}
\hline $\mathrm{CdCl}_{2}^{\circ}$ & - & - & 9.94 & 9.34 & - & 9.48 & - & - & - & 9.369 & - \\
\hline $\mathrm{Hg}^{2+}$ & - & 23.310 & - & - & - & - & - & 23.426 & - & - & - \\
\hline $\mathrm{HgCL}_{\overline{3}}$ & - & 9.816 & - & - & - & - & - & 9.965 & - & - & - \\
\hline $\mathrm{A}^{3}{ }^{3+}$ & 15.963 & 16.076 & 16.37 & $16.67^{\dagger}$ & & $16.15^{\dagger}$ & & 19.277 & 15.956 & 16.091 & 16.996 \\
\hline $\mathrm{Al}(\mathrm{OH})_{3}^{\circ}$ & 7.600 & - & 7.72 & - & - & $7.58^{\dagger}$ & - & - & - & 7.665 & - \\
\hline $\mathrm{Al}(\mathrm{OH})_{4}^{-}$ & 7.287 & 7.114 & 7.25 & $7.53^{\dagger}$ & - & $7.32^{\dagger}$ & - & 10.611 & 7.115 & 7.259 & 7.114 \\
\hline $\mathrm{Pb}^{2+}$ & 10.446 & 13.746 & 11.68 & - & - & - & - & 10.442 & - & 11.335 & - \\
\hline $\mathrm{PbCl}_{2}^{\circ}$ & 10.380 & 13.591 & 11.41 & - & - & - & - & 0.372 & - & 11.017 & - \\
\hline $\mathrm{PbCO}_{3}^{\circ}$ & - & 9.602 & 10.09 & - & - & - & - & 9.743 & - & 9.743 & - \\
\hline $\mathrm{NO}_{3}$ & 5.315 & - & 5.30 & - & - & - & - & - & 5.315 & 5.314 & 5.315 \\
\hline $\mathrm{PO}^{3}-\overline{-}$ & 9.979 & - & 10.48 & $11.81^{\dagger}$ & - & $11.76^{\dagger}$ & - & 10.126 & 10.482 & 10.480 & - \\
\hline $\mathrm{HPO}_{4}^{2-}$ & 6.858 & - & 7.02 & $8.48^{\dagger}$ & 6.673 & $8.48^{\dagger}$ & - & 6.897 & 6.989 & 6.988 & - \\
\hline $\mathrm{H}_{2} \mathrm{PO}_{4}^{-}$ & 8.474 & - & 8.49 & $9.93^{\dagger}$ & 8.295 & $10.06^{\dagger}$ & - & 8.449 & 8.382 & 8.381 & - \\
\hline $\mathrm{AsO}^{3} \frac{3}{4}$ & - & - & 11.01 & - & - & - & - & - & - & 10.007 & - \\
\hline $\mathrm{HAsO}_{4}^{3-}$ & - & - & 8.45 & - & - & - & - & - & - & 7.264 & - \\
\hline $\mathrm{I}^{-}$ & - & - & 6.30 & 6.30 & - & 6.31 & - & - & - & 6.296 & - \\
\hline
\end{tabular}

TMINEOL2 and REDEQL2 results were calcualted in such a way that the solution was equilibrated with supersaturated phases. $\mathrm{Si}, \mathrm{Al}, \mathrm{Fe}, \mathrm{Ca}, \mathrm{Sr}, \mathrm{Ba}, \mathrm{Zn}, \mathrm{SO}_{4}$, and $\mathrm{PO}_{4}$ species are not exactly comparable to the same species from the other programs because of this process, and of course, all species have been affected to some degree. 
Table VIII

Activity Coefficients of Selected Major Species in Sea Water

$\begin{array}{lccccccc}\text { PROGRAM }^{2} & \text { EQUIL } & \text { EQ3 } & \text { MIRE } & \text { SEAWAT } & \text { SOLMNEQ } & \text { WATEQF } & \text { WATEQ2 } \\ \mathrm{Ca}^{2+} & 0.245 & 0.245 & 0.231 & 0.245 & 0.244 & 0.249 & 0.249 \\ \mathrm{CaSO}_{4}^{\circ} & 1.172 & 1.000 & 0.507 & 1.150 & 1.180 & 1.170 & 1.170 \\ \mathrm{CaHCO}_{3}^{+} & 0.714 & 0.714 & 0.589 & 0.669 & 0.737 & 0.747 & 0.747 \\ \mathrm{CaCO}_{3}^{\circ} & 1.172 & 1.000 & 1.123 & 1.150 & 1.180 & 1.170 & 1.170 \\ \mathrm{Mg}^{2+} & 0.315 & 0.315 & 0.296 & 0.314 & 0.263 & 0.288 & 0.288 \\ \mathrm{MgSO}_{4}^{\circ} & 1.172 & 1.000 & 1.123 & 1.150 & 1.180 & 1.170 & 1.170 \\ \mathrm{MgHCO}_{3}^{+} & 0.671 & 0.670 & 0.589 & 0.669 & 0.670 & 0.747 & 0.747 \\ \mathrm{MgCO}_{3}^{\circ} & 1.172 & 1.000 & 0.387 & 1.150 & 1.180 & 1.170 & 1.170 \\ \mathrm{Na}^{+} & 0.671 & 0.670 & 0.631 & 0.688 & 0.670 & 0.706 & 0.706 \\ \mathrm{NaSO}_{4}^{-} & 0.683 & 0.682 & 0.589 & 0.669 & 0.720 & 0.747 & 0.747 \\ \mathrm{NaHCO}_{3}^{\circ} & 1.172 & - & 1.123 & 1.150 & 1.180 & 1.170 & 1.170 \\ \mathrm{~K}^{+} & 0.626 & 0.626 & 0.589 & 0.625 & 0.626 & 0.622 & 0.622 \\ \mathrm{KSO}_{4}^{-} & 0.650 & 0.647 & 0.589 & 0.669 & 0.720 & 0.747 & 0.747 \\ \mathrm{Cl}^{-} & 0.627 & 0.626 & 0.589 & 0.625 & 0.626 & 0.622 & 0.622 \\ \mathrm{SO}_{4}^{-} & 0.618 & 0.167 & 0.158 & 0.167 & 0.167 & 0.181 & 0.181 \\ \mathrm{HCO}_{3}^{-} & 0.690 & 0.690 & 0.631 & 0.669 & 0.720 & 0.675 & 0.747 \\ \mathrm{CO}_{3}^{-} & 0.188 & 0.187 & 0.195 & 0.190 & 0.222 & 0.207 & 0.311 \\ {\mathrm{~B}\left(\mathrm{OH}_{3}^{\circ}\right.}_{3}^{\circ} & 1.172 & - & - & - & 1.180 & 1.170 & 1.170 \\ {\mathrm{~B}\left(\mathrm{OH}_{-}^{-}\right.}_{4} & 0.671 & - & - & - & 0.605 & 0.747 & 0.747 \\ \mathrm{Br}^{-} & - & - & - & 0.625 & - & 0.747 & 0.747 \\ \mathrm{~F}^{-} & 0.650 & - & - & - & 0.649 & 0.747 & 0.747 \\ \mathrm{MgF}^{+} & - & - & - & - & 0.689 & 0.747 & 0.747 \\ \mathrm{Sr}^{2+} & 0.207 & - & - & - & 0.207 & 0.311 & 0.311 \\ \mathrm{H}_{4} \mathrm{Si}_{4}^{\circ} & 1.000 & - & 1.123 & - & 1.180 & 1.170 & 1.170 \\ \mathrm{H}^{+} & 0.804 & 0.805 & - & 0.750 & 0.804 & 0.747 & 0.747 \\ \mathrm{OH}^{-} & 0.650 & 0.649 & 0.589 & 0.685 & 0.649 & 0.747 & 0.747 \\ \mathrm{IOnic}^{-} & 0.663 & 0.677 & 0.655 & 0.660 & 0.666 & 0.680 & 0.680\end{array}$


Table IX

Saturation Index for Selected Minerals in River Water Test Case

\begin{tabular}{|c|c|c|c|c|c|c|c|c|c|}
\hline MINERAL & FORMULA & EQUIL & EQ3 & IONPAIR & MIRE & SOLMNEQ & WATEQF & WATEQ2 & WATSPEC \\
\hline Calcite & $\mathrm{CaCO}_{3}$ & -0.51 & -0.585 & -0.673 & -0.461 & -0.765 & -0.634 & -0.634 & -0.63 \\
\hline Dolomite & $\mathrm{CaMg}\left(\mathrm{CO}_{3}\right)_{2}$ & -0.73 & -0.248 & -1.340 & -0.730 & -1.329 & -1.384 & -1.386 & -1.38 \\
\hline Siderite & $\mathrm{FeCO}_{3}$ & -1.37 & +0.456 & - & -2.329 & -3.377 & -7.347 & -1.760 & -7.13 \\
\hline Rhodochrosite & $\mathrm{MnCO}_{3}$ & -1.81 & -3.225 & - & -2.097 & -2.136 & -2.180 & -2.180 & - \\
\hline Gypsum & $\mathrm{CaSO}_{4} \cdot 2 \mathrm{H}_{2} \mathrm{O}$ & -3.00 & -2.962 & - & -3.081 & -2.942 & -3.057 & -2.969 & -3.25 \\
\hline Celestite & $\mathrm{SrSO}_{4}$ & - & - & - & - & - & - & - & - \\
\hline Hydroxyapatite & $\mathrm{Ca}_{5}\left(\mathrm{PO}_{4}\right)_{3} \mathrm{OH}$ & +2.82 & - & - & +5.891 & +5.046 & -1.784 & -1.722 & - \\
\hline Fluorite & $\mathrm{CaF}_{2}$ & -4.39 & - & - & - & -3.338 & -3.079 & -3.074 & - \\
\hline Ferric Hydrox. (Am) & $\mathrm{Fe}(\mathrm{OH})_{3}$ & - & - & - & - & -7.584 & +1.304 & - & - \\
\hline Goethite & $\mathrm{FeO}(\mathrm{OH})$ & +5.59 & - & - & - & -1.484 & +7.810 & +6.843 & +5.06 \\
\hline Hematite & $\mathrm{Fe}_{2} \mathrm{O}_{3}$ & +8.11 & +18.332 & - & - & -3.252 & +15.144 & +13.223 & +13.52 \\
\hline Gibbsite (crypt.) & $\mathrm{Al}(\mathrm{OH})_{3}$ & -0.08 & +1.948 & - & - & -0.058 & -0.336 & -1.989 & -1.19 \\
\hline Birnessite & $\mathrm{MnO}_{2}$ & - & - & - & - & - & -4.114 & -4.114 & - \\
\hline Chalcedony & $\mathrm{SiO}_{2}$ & - & +0.490 & - & - & +0.217 & -0.142 & +0.189 & - \\
\hline Quartz & $\mathrm{SiO}_{2}$ & +0.47 & +0.776 & - & - & +0.697 & +0.405 & +0.736 & +0.74 \\
\hline Kaolinite & $\mathrm{Al}_{2} \mathrm{Si}_{2} \mathrm{O}_{5}(\mathrm{OH})_{4}$ & +1.83 & +5.826 & - & - & - & +1.638 & -1.021 & +2.32 \\
\hline Sepiolite & $\mathrm{Mg}_{2} \mathrm{SiO}_{7 \cdot 5}(\mathrm{OH}) \cdot 3 \mathrm{H}_{2} \mathrm{O}$ & -4.55 & - & - & - & -5.734 & -3.699 & - & - \\
\hline FeS Amorphous & $\mathrm{FeS}$ & - & - & - & - & - & -7.644 & -2.313 & - \\
\hline Mackinawi te & $\mathrm{FeS}$ & - & - & - & - & - & -6.928 & -1.580 & - \\
\hline
\end{tabular}

$+2$

(a) 
Table $X$

Saturation Index for Selected Minerals in Seawater Test Case

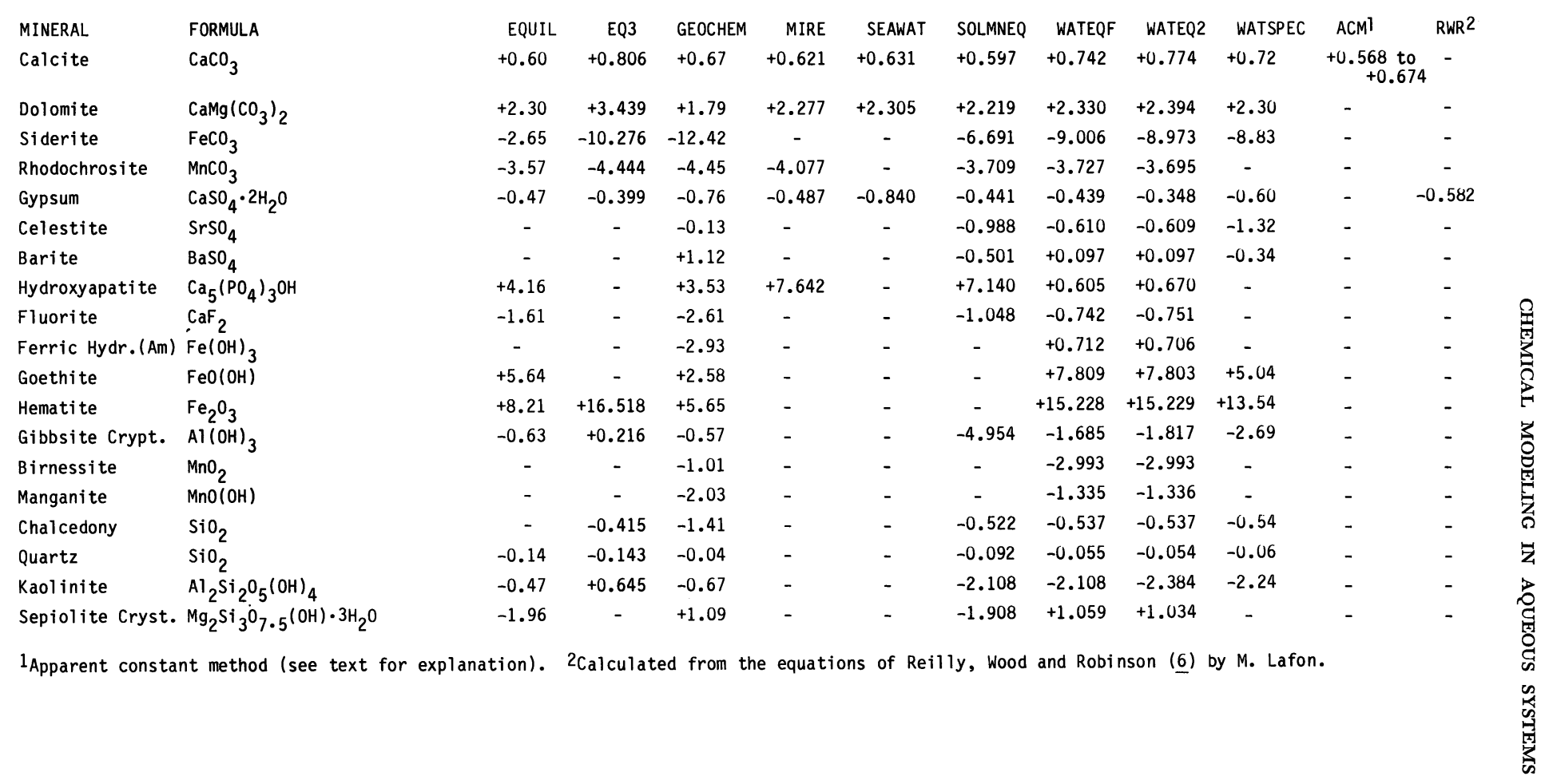


through the approach offered by Haas and Fisher (77) but it will take some time to compile and evaluate the appropriate data. In the meantime the lack of carefully evaluated thermodynamic data will continue to be the most serious limitation for any type of chemical modeling.

Thirdly, another corollary of the first limitation, is the inconsistency and inadequacy of activity coefficient equations. Some models use the extended Delbye-Huckel equation (EDH), others the extended Debye-Huckel with an additional linear term (B-dot, 78, 79) and others the Davies equation (some with the constant 0.2 and some with $0.3,80)$. The activity coefficients given in Table VIII for seawater show fair agreement because seawater ionic strength is not far from the range of applicability of the equations. However, the accumulation of errors from the consideration of several ions and complexes could lead to serious discrepancies. Another related problem is the calculation of activity coefficients for neutral complexes. Very little reliable information is available on the activity of neutral ion pairs and since these often comprise the dominant species in aqueous systems their activity coefficients can be an important source of uncertainty.

The fourth limitation is the assumption made about the redox state of aqueous systems. The distribution of redox species depends on what redox potential is assumed to dominate the chemical equilibrium. The possible alternatives include the

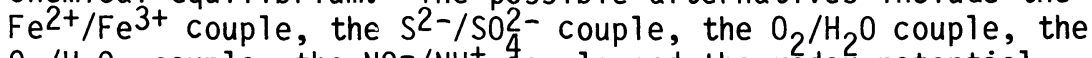
$\mathrm{O}_{2} / \mathrm{H}_{2} \mathrm{O}_{2}$ couple, the $\mathrm{NO}_{3} / \mathrm{NH}_{4}^{+}$couple and the redox patential measured with a platinum efectrode. The wide range of values for iron, manganese, chromium and arsenic species is partly due to the inherent redox assumptions. To examine how different redox controls affect the distribution of species while other factors are kept constant, several redox options were computed on WATEQ2 for both test cases. These results are shown in Table XI. The redox elements, iron and arsenic, can be distributed according to several imposed redox potentials given total concentrations of iron and arsenic. Ferrous and ferric ions along with the two dominant forms of oxidized and reduced arsenic were computed by all the possible redox options. The range of concentrations of these species is several orders of magnitude and includes most of the values listed in Tables $V$ and VII. If the application of a chemical model is to interpret natural water chemistry, including redox reactions, then individual redox elements such as total ferrous and total ferric should be analyzed separately when possible rather than assuming that they can be distributed according to some other equilibrium. Homogeneous redox equilibrium may not be often obtained in real systems (81) and imposed redox equilibria may not represent a realistic distribution of species.

A fifth factor is the total number of complexes considered by an aqueous model. If one model has 2 or 3 times as 
Table XI

Variations in the distribution of selected redox species (in $\mathrm{p}(\underline{\mathrm{m}})$ ) caused by changing the imposed redox potential.

River Water Test Case

\begin{tabular}{|c|c|c|c|c|c|}
\hline $\begin{array}{l}\text { Imposed Redox } \\
\text { Potential }\end{array}$ & $\begin{array}{l}\text { Implied } \\
\text { Eh(volts) }\end{array}$ & $\mathrm{Fe}^{2+}$ & $\mathrm{Fe}^{3+}$ & $\mathrm{H}_{2} \mathrm{As}_{3}^{\circ}$ & $\mathrm{HAsO}_{4}^{2-}$ \\
\hline Pt Eh & 0.440 & 11.78 & 17.25 & 25.80 & 7.60 \\
\hline $\mathrm{O}_{2} / \mathrm{H}_{2} \mathrm{O}$ & 0.783 & 17.89 & 17.25 & 38.03 & 7.60 \\
\hline $\mathrm{O}_{2} / \mathrm{H}_{2} \mathrm{O}_{2}$ & 0.141 & 6.81 & 17.61 & 15.14 & 7.60 \\
\hline $\mathrm{NO}_{3} / \mathrm{NO}_{2}$ & 0.445 & 11.87 & 17.25 & 25.98 & 7.60 \\
\hline $\mathrm{NO}_{3}^{-} / \mathrm{NH}_{4}^{+}$ & 0.328 & 9.78 & 17.25 & 21.81 & 7.60 \\
\hline $\mathrm{s}^{2-}-\mathrm{SO} \mathrm{S}_{4}^{2-}$ & -0.532 & 6.56 & 29.36 & 7.59 & 24.04 \\
\hline $\mathrm{Fe}^{2+} / \mathrm{Fe}^{3+}$ & 0.073 & 6.58 & 18.50 & 12.72 & 7.60 \\
\hline \multicolumn{6}{|c|}{ Seawater Test Case } \\
\hline Pt Eh & 0.550 & 13.94 & 17.90 & 29.17 & 7.26 \\
\hline $\mathrm{O}_{2} / \mathrm{H}_{2} \mathrm{O}$ & 0.731 & 17.85 & 17.90 & 36.98 & 7.26 \\
\hline $\mathrm{O}_{2} / \mathrm{H}_{2} \mathrm{O}_{2}$ & 0.133 & 7.94 & 18.09 & 16.76 & 7.26 \\
\hline $\mathrm{NO}_{3} / \mathrm{NO}_{2}$ & 0.390 & 12.08 & 17.90 & 25.45 & 7.26 \\
\hline $\mathrm{NO}_{3}^{-} / \mathrm{NH}_{4}^{+}$ & 0.269 & 10.04 & 17.90 & 21.36 & 7.26 \\
\hline
\end{tabular}

many metal-ligand complexes as another model then it will have a lower concentration of free ligand, assuming negligible differences in the data base. For example, the inclusion of the calcium and magnesium chloride complexes by GEOCHEM tends to lower the free calcium, magnesium and chloride ion concentrations below those of the other models.

A sixth source of difference, which was unavoidable in preparation of the test cases, is the various ways each program handles the carbonate system. From a practical standpoint, the inorganic carbon system of natural waters is usually determined from the titration alkalinity. Because the titration alkalinity includes both cartonate and non-carbonate alkalinity, the titration alkalinity must be corrected for noncarbonate alkalinity. Most models correct for the presence of $\mathrm{H}_{2} \mathrm{BO}_{3}^{-}$and $\mathrm{H}_{3} \mathrm{SiO}_{4}^{-}$but many other minor species should be considered and there is no general agreement as to the precise correction for non-carbonate alkalinity. In devising the correction used originally in WATEQ, Truesdell and Jones also 
considered the possibility that some non-carbonate alkalinity species were kinetically slow to react in the titration and thus were not included in the titration alkalinity. Even if we could agree on which species to subtract from the titration alkalinity, the computed carbonate system is still dependent on the equilibrium constants and activity coefficients used by the model to compute the actual concentrations of non-carbonate alkalinity species.

Some aqueous models accept only total inorganic carbon rather than titration alkalinity or carbonate alkalinity. For this reason, the sea water analysis of Table III includes total inorganic carbon which was calculated from $\mathrm{pH}$, total alkalinity and salinity using the apparent sea water constants of Mehrbach et al.(82) for the dissociation of carbonic acid and the boric acid dissociation constant of Lyman (83), as expressed by $\mathrm{Li}$ et al. (84).

Certainly, there are differences in aqueous models in current use and the carbonate calculations will depend in part on whether the source of carbon data was total alkalinity or total inorganic carbon from Table III. For example, using the program WATEQF and data in ppm from Table III, Table XII compares some computed parameters of the carbonate system of seawater using total alkalinity and total inorganic carbon from Table III.

\section{Table XII}

\section{Comparison of carbonate parameters computed by} WATEQF in Seawater Test Case

\section{Inorganic Carbon Data Source}

\begin{tabular}{|c|c|c|}
\hline $\begin{array}{l}\text { Computed } \\
\text { Parameter } \quad(=\end{array}$ & $\begin{array}{l}\text { Total Alkalinity } \\
141.682 \mathrm{ppm} \text { as } \mathrm{HCO}_{3} \text { ) }\end{array}$ & $\begin{array}{l}\text { Total Inorganic Carbon } \\
\left(=2.09566 \times 10^{-3} \underline{m}\right)\end{array}$ \\
\hline Total carbon (m) & $2.1421 \times 10^{-3}$ & $2.0957 \times 10^{-3}$ \\
\hline $\begin{array}{l}\mathrm{mHCO}_{3}^{-} \\
\mathrm{mCO}_{2}^{2} \\
\log ^{3} \mathrm{P}_{\mathrm{CO}_{2}}\end{array}$ & $\begin{array}{l}1.4961 \times 10^{-3} \\
3.7880 \times 10^{-5} \\
-3.399\end{array}$ & $\begin{array}{l}1.4636 \times 10^{-3} \\
3.7057 \times 10^{-5} \\
-3.409\end{array}$ \\
\hline SI calcite & 0.7418 & 0.7323 \\
\hline
\end{tabular}

The differences shown in Table XII are really quite small and well within the uncertainties of the thermodynamic data of the aqueous model. The close agreement shown in Table XII indicates that the carbonate system of WATEQF is reasonably compatible with the apparent constants of Mehrbach et al. (82) and Lyman (83). However, in comparing results in the carbonate system computed by other aqueous models, there is a 
potential for differences depending on the compatibility of the equilibrium constants and activity coefficients used with the apparent constant approach for seawater.

A seventh limitation is the fact that not all of the aqueous models compute temperature corrections. The programs of the REDEQL school and those used in analytical chemistry contain a data base of equilibrium constants at $25^{\circ} \mathrm{C}$ and are not as reliable at other temperatures. Since the river water test case was given a temperature of $9.5^{\circ} \mathrm{C}$ there will be some differences between programs that correct for temperature and those that do not. The temperature correction can cause substantial changes in computed results when interpreting the chemistry of natural waters because these systems commonly vary both diurnally and seasonally over a large range in temperature and because many equilibrium constants are strongly temperature dependent.

If all of these limitations were overcome, the aqueous models described here should give consistent results. To reemphasize, the largest single source of discrepancy is the thermodynamic data base used by each model. This limitation is not apparent among the major species in a dilute solution but as the ionic strenth increases and/or the concentration of the constituent decreases, the discrepancies markedly increase. This problem becomes particularly acute for trace elements where apparently small changes in equilibrium constants or $\mathrm{pH}$ or redox potential or temperature may produce very large changes in trace element speciation.

The effect of the thermodynamic data is particularly striking from a comparison of saturation indices in Tables IX and $X$. The mineral showing the best agreement in both test cases is calcite which would be expected since its properties have been extensively studied, especially in the marine environment. Using the apparent constant method the SI of calcite in seawater varies from 0.568 to 0.674 depending on the choice of data. The low value is that of Berner (90) which is compatible with the apparent dissociation constants for carbonic acid in seawater of Lyman (83). The high value is from Ingle et al. (88) which is compatible with the dissociation constants of Mehrbach et al. (82). In the river water test case gypsum SI values show very good agreement but for many other minerals there is considerable disagreement of one order of magnitude or more. SI values for several minerals show both supersaturation and undersaturation and these conditions are particularly striking for hydroxyapatite, goethite, hematite and kaolinite. In the seawater test case gypsum does not show as good agreement as in river water with values ranging from -0.35 to -0.84 . Many minerals again show more than an order of magnitude difference in SI values. From an examination of these tables it should be clear that any interpretation of mineral saturation states in an aquatic environment depends 
greatly on the chosen chemical model which, in turn, depends upon the reliability of the thermodynamic data base and any inherent assumptions of the behavior of electrolyte solutions.

Summary

In this review over 30 computerized chemical models have been described which can calculate the distribution of species in an aqueous system at equilibrium. Every computerized model was developed for somewhat different purposes and there is no general purpose model which can be used for all of the applications described in this report. However, an attempt has been made to point out the major differences between models as a guide to researchers interested in chemical modeling. The applications include titration simulation, solubility testing, adsorption modeling, ion exchange modeling, and progressive mass transfer reactions in heterogeneous systems. Two hypothetical test cases: a dilute river water analysis and a seawater analysis were run on a total of 13 different programs to determine the distribution of species and the saturation indices for several minerals. A comparison of these results demonstrate generally good agreement for the major species and rather poor agreement for the minor species. The major source of discrepancy is the thermodynamic data base used by the various models. Other important limitations include the number of complexes in each model, the form of the activity coefficient equation, the redox assumptions, the form of the alkalinity input and the non-carbonate alkalinity correction, and temperature and pressure corrections. The discrepancies in the test case results indicate that a great deal of caution must be exercised when interpreting aqueous chemical equilibria by a chemical modeling approach. More attention should be paid to the assumptions of a model and a great deal more work is needed on the evaluation of thermodynamic data in order to provide a consistent set of values.

\section{Abstract}

A survey of computer programs which are currently being used to calculate the distribution of species in aqueous solutions, especially natural waters, has been made in order to 1) provide an inventory of available programs with a short description of their uses, 2) compare the consistency of their output for two given test solutions and 3 ) identify major weaknesses or problems encountered from their use. More than a dozen active programs which can be used for distribution of species and activity calculations for homogeneos equilibria among the major anions and cations of natural waters have been inventoried. Half of these programs can also accept several trace elements including $\mathrm{Fe}, \mathrm{Al}, \mathrm{Mn}, \mathrm{Cu}, \mathrm{Ni}, \mathrm{Zn}, \mathrm{Cd}, \mathrm{Pb}, \mathrm{Ag}, \mathrm{Hg}, \mathrm{As}$, 
$\mathrm{Ba}, \mathrm{Sr}$, and B. Consistency between programs was evaluated by comparing the log of the molal concentrations of free ions and complexes for two test solutions: a hypothetical seawater analysis and a hypothetical river water analysis. Comparison of the free major ion concentrations in the river water test case shows excellent agreement for the major species. In the seawater test case there is less agreement and for both test cases the minor species commonly show orders of magnitude differences in concentrations. These differences primarily reflect differences in the thermodynamic data base of each chemical model although other factors such as activity coefficient calculations, redox assumptions, temperature corrections, alkalinity corrections and the number of complexes used all have an affect on the output.

\section{Literature Cited}

1. Leggett, D. J. Machine computation of equilibrium concentrations - some practical considerations, Talanta 24 , 535-542 (1977).

2. Perrin, D.D. Recent applications of digital computers in analytical chemistry, Talanta 24, 339-345 (1977).

3. Bjerrum, N. Ionic association I. Influence of ionic association on the activity of ions at moderate degrees of association, $\mathrm{Kgl}$. Danske Videnskab. Selskab. Math-fys. Medd. 7, 1-48 (1926).

4. Fuoss, R. M. Properties of electrolyte solutions, Chem. Rev. $17,27-42(1935)$.

5. Bockris, J. O'M. and Reddy, A. K. N. "Modern Electrochemistry," 622 p. Plenum Press, New York, 1970.

6. Reilly, P. J., Wood, R. H. and Robinson, R. A. Prediction of osmotic and activity coefficients in mixed-electrolyte solutions, J. Phys. Chem. 75, 1305-1315 (1971).

7. Othmer, H. G. Nonuniqueness of equilibria in closed reacting systems, Chem. Eng. Sci. 31, 993-1003 (1976).

8. Caram, H. S. and Scriven, L. E. Nonunique reaction equilibria in non-ideal systems, Chem. Eng. Sci. 31, 163-168 (1976).

9. Zeleznik, F. J. and Gordon, S. Calculation of complex chemical equilibria, Ind. Eng. Chem. 60, 27-57 (1968).

10. Van Zeggeren, F. and Storey, S. H. "The Computation of Chemical Equilibria," 176 p. Cambridge University Press, London, England, 1970.

11. Brinkley, S. R. Notes on the condition of equilibrium for systems of many constituents, J. Chem. Phys. 14, 563-564 (1946).

12. Brinkley,, S. R., Calculation of the equilibrium composition of systems of many constituents, J. Chem. Phys. 15, 107-110 (1947). 
13. Kandiner, H. J. and Brinkley, S. R. Calculation of complex equilibrium relations, Ind. Eng. Chem. 42, 850-855 (1950).

14. Feldman, H. F., Simons, W. H. and Bienstock, D. Calculating equilibrium compositions of multicomponent, multiphase, chemical reacting systems, U.S. Bur. Mines Rep. Invest. 7257, $22 \mathrm{p}$. (1969).

15. Crear, D. A method for computing multicomponent chemical equilibria based on equilibrium constants, Geochim. Cosmochim. Acta 39, 1375-1384 (1975).

16. Acton, F. S. "Numerical Methods that Work," 541 p. Harper and Row, New York, 1970.

17. White, W. B., Johnson, S. M. and Dantzig, G. B. Chemical equilibrium in complex mixtures, J. Chem. Phys. 28, 751-755 (1958).

18. Dayhoff, M.0., Lippincott, E. R., Eck, R. V. and Nagarajan, G. Thermodynamic equilibrium in prebiological atmospheres of $\mathrm{C}, \mathrm{H}, \mathrm{O}, \mathrm{N}, \mathrm{P}, \mathrm{S}$ and $\mathrm{Cl}, \mathrm{NASA} \mathrm{SP}-3040$, Washington, D.C., 260 p. 1967.

19. Holloway, J. R. and Reese, F. 0 . The generation of $\mathrm{N}_{2}-\mathrm{CO}_{2}-\mathrm{H}_{2} \mathrm{O}$ fluids for use in hydrothermal experimentation I. Experimental method and equilibrium calculations in the C-0-H-N system, Amer. Mineral. 59, 587-597 (1974).

20. Karpov, I. K. and Kaz'min, L. A. Calculation of geochemical equilibria in heterogeneous multicomponent systems, Geochem. Int. 9, 252-265 (1972).

21. Ingri, N., Kakolowicz, W., Sillen, L. G. and Warnquist, B. High-speed computers as a supplement of graphical methods - V. HALTAFALL, a general program for calculating the composition of equilibrium mixtues, Talanta 14, 12611286 (1967).

22. Dyrssen, D., Jagner, D. and Wengelin, F. "Computer Calculation of Ionic Equilibria and Titration Procedures," 250 p. John Wiley, New York, 1968.

23. Ingri, N. and Sillen, L. G. High-speed computers as a supplement of graphical methods IV. An ALGOL version of LETAGROP VRID, Arkiv. Kemi 23, 97-121 (1965).

24. Perrin, D. D. MuTtiple equiTibria in assemblages of metal ions and commplexing species: a model for biological systems, Nature 206, 170-171 (1965).

25. Perrin, D. D. and Sayce, I. G. Computer calculation of equilibrium concentrations in mixtures of metal ions and complexing species, Talanta 14, 833-842 (1967).

26. Fardy, J. J. and Sylva, R. N. SIAS, a computer program for the generalized calculation of speciation in mixed metal-1igand aqueous systems, AAEC/E445, Lucas Heights, Australia, 20 p. (1978).

27. Detar, D. F. "Computer Programs for Chemistry," Vo1. II, 260 p. W. A. Benjamin, New York, 1969. 
28. Bos, M. and Meershoek, H. Q. J. A computer program for the calculation of equilibrium concentrations in complex systems, Anal. Chim. Acta 61, 185-194 (1972).

29. Garrels, R. M. and Thompson, M. E., A chemical model for seawater at $25^{\circ} \mathrm{C}$ and one atmosphere total pressure, Amer. J. Sci. 260, 57-66 (1962).

30. Barnes, I. and Clarke, F. E., Chemical properties of ground water and their encrustation effects on wells, U.S. Geo1. Survey Prof. Paper 498-D, 58 p. (1969).

31. Helgeson, H. C., Brown, T. H., Nigrini, A. and Jones, T. A., Calculation of mass transfer in geochemical processes involving aqueous solutions, Geochim. Cosmochim. Acta. 34, 569-592 (1970).

32. Fritz, B. "Etude thermodynamique et simulation des reactions entre mineraux et solutions application a la geochemie des alterations et des eaux continentales." PhD. Thesis, Univ. Louis Pasteur, Strasbourg, France, 152 p., 1975.

33. Droubi, A. Geochimie des sels et des solutions concentrees pars evaporation. Modele thermodynamique de simulation. Application aux sols sales du Tchad. Ph.D. Thesis, Univ. Louis Pasteur, Strasbourg, France, 177 p., 1976.

34. Truesde11, A. H. and Jones, B. F. WATEQ, a computer program for calculating chemical equilibria of natural waters, NTIS Tech. Rept. PB2-20464 Springfield,VA 77 p. (1973).

35. Truesdel1, A. H. and Jones, B. F. WATEQ, a computer program for calculating chemical equilibria of natural waters, J. Res. U. S. Geol. Survey 2, 233-274 (1974).

36. Kharaka, Y. K. and Barnes, I., SOLMNEQ: Solution-mineral equilibrium computations, NTIS Tech. Rept. PB214-899, Springfield, VA 82 p. (1973).

37. Wolery, T. J., Some chemical aspects of hydrothermal processes at mid-oceanic ridges - a theoretical study. I. Basalt - sea water reaction and chemical cycling between the coeanic crust and the oceans. II. Calculation of chemical equilibrium between aqueous solutions and minerals, Ph.D. Thesis, Northwestern Univ., Evanston, IL, 1978.

38. Plummer, L. N., Jones, B. F. and Truesde11, A. H., WATEQF - a FORTRAN IV version of WATEQ, a computer program for calculating chemical equilibrium of natural waters, U.S. Geol. Survey Water Resour. Invest. $76-13,61$ p. (1976).

39. Lueck, S. L., Runnells, D. D. and Markos, G., Computer modelling of urnaium species in natural waters: applications to exploration, Geol. Soc. Amer. Ann. Mtg. Abstracts, 1978.

40. Bal1, J. W., Jenne, E. A. and Nordstrom, D. K., WATEQ2 - a computerized chemical model for trace and major element speciation and mineral equilibria of natural waters, in 
Jenne, E. A., ed., "Chemical Modeling in Aqueous Systems. Speciation, Sorption, Solubility, and Kinetics," Amer. Chem. Soc., 1978 (This volume).

41. WigTey, T.M.L. WATSPEC: a computer program for determining the equilibrium speciation of aqueous solutions, Brit. Geomorph. Res. Group Tech. Bu11. 20, 48 p. (1977).

42. Wigley, T. M. L., Ion pairing and water quality measurements, Can. J. Earth Sci. 8, 468-476 (1971).

43. Wolery, T. J. and Walters, L. J., Jr., Calculation of equilibrium distributions of chemical species in aqueous solutions by means of monotone sequences, Math Geol. 7, 99-115 (1975).

44. Walters, L. J., Jr. and Wolery, T. J., A monotonesequences algorithm and FORTRAN IV program for calculation of equilibrium distributions of chemical species, Comp. Geosci. 1, 57-63 (1975).

45. Lafon, G. M., Some quantitative aspects of the chemical evolution of the oceans, Ph.D. Thesis, Northwestern Univ., Evanston, IL., 136 p., 1969.

46. Holdren, G. R., Jr., Distribution and behavior of manganese in the interstitial waters of Chesapeake Bay sediments during early diagenesis, Ph.D. Thes is, The Johns Hopkins Univ., Baltimore, MD, 191 p., 1977.

47. Thrailkill, J., Solution geochemistry of the water of limestone terrains, Univ. Kentucky Water Resour. Inst. Res. Rept. 19, $125 \mathrm{p}(1970)$.

48. Van Beek, C. G. E. M., personal communication.

49. Van Breeman, N. Calculation of ionic activities in natural waters, Geochim. Cosmochim. Acta 37, 101-107 (1973). (1973).

50. Morel, F. and Morgan, J. J. A numerical method for computing equilibria in aqueous chemical systems, Env. Sci. Tech. 6, 58-67 (1972).

51. Morel, F., McDuff, R. E. and Morgan, J. J. Interactions and chemostasis in aquatic chemical systems: Role of $\mathrm{pH}$, $\mathrm{pE}$, solubility and complexation, p. 157-200, in Singer, P.C., ed., "Trace Metals and Metal-Organic Interactions in Natural Waters," Ann Arbor Science Publishers, Ann Arbor, Michigan, 1973.

52. Morel, F., McDuff, R. E. and Morgan, J. J. Theory of interaction intensities, buffer capacities, and $\mathrm{pH}$ stability in aqueous systems, with application to the $\mathrm{pH}$ of seawater and a heterogeneous model ocean system, Mar. Chem. 4, 1001-1028 (1976).

53. James, R. 0. and Healy, T. W. Adsorption of hydrolyzable metal ions at the oxide-water interface. I. Cobalt (II) adsorption on silicon dioxide and titanium dioxide as model systems II. Charge reversal of silicon dioxide and titanium dioxide colloids by adsorbed cobalt (II), lanthanum (III) and thorium (IV) as model systems III. 
Thermodynamic model of adsorption, J. Colloid Interface Sci. 40, 42-81 (1972).

54. Schindler, P. W. and Gamsjaeger, H. Acid-base reactions of the titanium dioxide (anatase) - water interface and the point of zero charge of titanium dioxide suspension, Kolloid - Z. Z. Polym. 250, 759-763 (1972).

55. Schindler, P. W., Fuerst, B., Dick, R., Wolfe, P. U. Ligand properties of surface silanol groups. I. Surface complex formation with iron $(3+)$, copper $(2+)$, cadmium $(2+)$ and lead $(2+)$, J. Colloid Interface Sci. 55, 469-475 (1976).

56. Schindler, P. W., Waelti, E. and Fuerst, B. The role of surface hydroxyl roups in the surface chemistry of metal oxides, Chimia 30, 107-109 (1976).

57. Hohl, H. and Stumm, W. Interaction of lead $(2+)$ with hydrous-alumina, J. Colloid Interface Sci. 55, 281-288 (1976).

58. Westal1, J. and Hohl, H. A general method for the computation of equilibria and determination of equilibrium constants for adsorption at hydrous oxide surfaces, in "Abstracts of Papers," Amer. Chem. Soc. Meeting, Miami Beach, FL., 1978.

59. Davis, J. A., III and Leckie, J.0. Surface ionization and complexation at the oxide/water interface, in Jenne, E. A., ed. "Chemical Modeling in Aqueous Systems. Speciation, Sorption, Solubility, and Kinetics." Amer. Chem. Soc., 1978 (This volume).

60. Westa11, J. C., Zachary, J. L. and Morel F. M. M. MINEQL, a computer program for the calculation of chemical equilibrium composition of aqueous system, Tech. Note 18, Dept.Civil Eng. Mass. Inst. Tech., Cambridge, MA., 91 p., (1976).

61. Mattigod, S. V. and Sposito, G. Chemical modeling of trace metal equilibria in contaminated soil solutions using the computer program GEOCHEM, in Jenne, E.A., ed., "Chemical Modeling in Aqueous Systems. Speciation, Sorption, Solubility, and Kinetics." Amer. Chem. Soc., 1978 (This volume).

62. I, T.-P. and Nancollas, G.H. EQUIL - a computational method for the calculation of solution equilibria, Anal. Chem. 44, 1940-1950 (1972).

63. Helgeson, H. C. Evaluation of irreversible reactions in geochemical processes involving minerals and aqueous solutions - I. Thermodynamic relations, Geochim. Cosmochim. Acta 32, 853-877 (1968).

64. Helgeson, H. C., Garrels, R. M. and Mackenzie, F. T. Evaluation of irreversible reactions in geochemical processes involving minerals and aqueous solutions - II. Applications, Geochim. Cosmochim. Acta 33, 455-481 (1969).

65. DeDonder, Th. and Van Rysselberghe, P. "The Thermodynamic Theory of Affinity," Stanford University Press, Stanford, California, 1936. 
66. Helgeson, H. C. A chemical and thermodynamic model of ore deposition in hydrothermal systems, Mineral Soc. Amer. Spec. Paper 3, 155-186 (1970).

67. Miller, D. G., Piwinskii, A. J. and Yamauchi, R. The use of geochemical-equilibrium computer calculations to estimate precipitation from geothermal brines, UCRL -52197 Livermore, Calif., 34 p., (1977).

68. Droubi, A., Cheverry, C., Fritz, B. and Tardy, Y. Geochimie des eaux et des sels dans les sols des polders du Lac Tchad: Application d'un modele thermodynamique de simulation de 1'evaporation, Chem. Geol. 17, 165-177 (1976).

69. Droubi, A., Fritz, B. and Tardy, Y. Equilibres entre mineraux et solutions; Programmes de calcul appliques a la prediction de la sahire des sols et des doses optimales d'irrigation, Cah. ORSTOM, ser. Pedol XIV, 13-38 (1976).

70. Gear, C. W. The automatic integration of ordinary differential equations, Communications of the ACM 14, 176-179 (1971).

71. Gear, C. W. Algorithm 407-DIFSUB for solution of ordinary differential equations, Communications of the ACM 14, 185190 (1971).

72. Plummer, L. N., Parkhurst, D. L. and Kosiur, D. R. MIX2: A computer program for modeling chemical reactions in natural waters, U.S. Geol. Survey Water Resour. Inv. Rept. 75-61, 73 p. (1975).

73. Plummer, L. N. Mixing of sea water and calcium carbonate ground water, Geol. Soc. Amer. Mem. 142, 219-236 (1975).

74. Wigley, T. M. L. and Plummer, L. N. Mixing of carbonate waters, Geochim. Cosmochim. Acta 40, 989-995 (1976).

75. Plummer, L. N. Defining reactions and mass transfer in part of the Floridan aquifer, Water Resour. Res. 13, 801-812 (1977).

76. Parkhurst, D. L. Plummer, L. N. and Thorstenson, D. C. Chemical models in ground-water systems, Geol. Soc. Amer. Ann. Mtg. Abstracts 1978.

77. Haas, J. L., Jr. and Fisher, J. R. Simultaneous evaluation and correlation of thermodynamic data, Amer. J. Sci. 276, 525-545 (1976).

78. Helgeson, H. C. Thermodynamics of hydrothermal systems at elevated temperatures and pressures, Amer. J. Sci. 267, 729804 (1969).

79. Helgeson, H. C. and Kirkham, D. H. Theoretical prediction of the thermodynamic behavior of aqueous electrolytes at high pressures and temperatures II. Debye-Huckel parameters for activity coefficients and relative partial molal properties, Amer. J. Sci. 274, 1199-1261 (1974).

80. Davies, C. W. "Ion Association," 190 p. Butterworths, Washington, D.C., 1962. 
81. Morris, J. C. and Stumm, W. Redox equilibria and measurements of potentials in the aquatic environment, p.270-285, in Gould, R. F., ed., "Equilibrium Concepts in Natural Water Systems," Adv. Chem. Ser. 67, 1967.

82. Mehrbach, C., Culberson, C. H., Hawley, J. E. and Pytkowicz, R. M. Measurement of the aparent dissociation constants of carbonic acid in seawater at atmospheric pressure, Limno1. Oceanogr. 18, 897-907 (1973).

83. Lyman, J. Buffer mechanism of seawater, Ph.D. Thes is, Univ. Calif., Los Angeles, CA., 196 p., 1956.

84. Li, Y. H., Takahashi, T. and Broecker, W. S., Degree of saturation of $\mathrm{CaCO}_{3}$ in the oceans, J. Geophys. Res. 74, 5507-5525 (1969).

85. McDuff, R. E. and Morel, F. M., Description and use of the chemical equilibrium program REDEQL2, Keck Lab. Tech. Rept. EQ-73-02, Cal if, Inst. Tech., Pasadena, CA, 75., (1973).

86. Holdren, G. R., Jr. and Bricker, 0.P., Distribution and control of dissolved iron and manganese in the interstitial waters of the Chesapeake Bay, p. 178-196, in Drucker, $H$. and Wildung, R. E., ed., "Biological Implications of Metals in the Environment," ERDA Symposium Series 42. 1977.

87. Thrailkill, J., Carbonate chemistry of aquifer and stream water in Kentucky, J. Hydrol. 16, 93-104 (1972).

88. Thrailkill, J., Carbonate equilibria in karst waters, p. 745771 , in Yevjevich, V., ed., "Karst Hydrology and Water Resources," Vol.2, Water Resources Pub., Ft. Collins, C0., 1976.

89. Wigley, T. M. L., Plummer, L. N., and Pearson, F. J., Jr., Mass transfer and carbon isotope evolution in natural water system, Geochim. Cosmochim. Acta 42, 1117-1139 (1978).

90. Berner, R. A., The solubility of calcite and aragonite in seawater at atmospheric pressure and $34.50 / 00$ salinity, Amer. J. Sci. 276, 713-730 (1976).

RECEIVED November 16, 1978.

${ }^{2}$ Department of Environmental Sciences, University of Virginia, Charlottesville, VA 22903.

${ }^{3}$ U.S. Geological Survey, National Center, MS 432, Reston, VA 22092.

${ }^{4}$ Climatic Research Unit, University of East Anglia, Norwich, NR4 7TJ, England.

${ }^{5}$ Lawrence Livermore Laboratory, University of California, P.O. Box 808, Livermore, CA 94550.

${ }^{6}$ U.S. Geological Survey, WRD, 345 Middlefield Rd., MS 21, Menlo Park, CA 94025.

${ }^{7}$ U.S. Geological Survey, Denver Federal Center, MS 416, Box 25046, Lakewood, CO 80225.

${ }^{8}$ Department of Geological \& Geophysical Sciences, Princeton University, Princeton. NJ 08540.

${ }^{9}$ Australian Atomic Energy Commission Research Establishment, Lucas Heights, N.S.W., Australia.

${ }^{10}$ Institut de Geologie, 1, rue Blessig, 67084 Strasbourg, France.

${ }^{11}$ Department of Civil and Mineral Engineering, University of Minnesota, Minneapolis, MN 55455.

${ }_{12}$ Department of Geological Sciences, University of Rochester, Rochester, NY 14627.

${ }^{13}$ Department of Earth \& Planetary Sciences, The Johns Hopkins University, Baltimore, MD 21218.

${ }_{14}$ Department of Soil \& Environmental Sciences, University of California, Riverside, CA 92521.

${ }_{15}$ Department Civil Engineering, Massachusetts Institute of Technology, Cambridge, MA 02139.

${ }^{16}$ State of New York Dept. of Health, New Scotland Avenue, Albany, NY 12201.

${ }^{17}$ Department of Geology, University of Kentucky, Lexington, KY 40506. 